\title{
Substrate geology controlling different morphology, sedimentology, diagenesis and geochemistry of adjacent travertine bodies: a case study from the Sanandaj-Sirjan zone (western Iran)
}

Zahra, Mohammadi ${ }^{*}$, Enrico Capezzuoli $^{2}$, Hannes Claes ${ }^{3}$, Reza Alipoor ${ }^{4}$, Philippe Muchez ${ }^{1}$, Rudy Swennen ${ }^{1}$

${ }^{1}$ Department of Earth and Environmental Sciences, KU Leuven, Celestijnenlaan 200E, Leuven B-3001, Belgium

${ }^{2}$ Department of Earth Sciences, University of Florence, Florence, Italy

${ }^{3}$ Clay and Interface Mineralogy (CIM), RWTH Aachen University, Aachen, Germany.

${ }^{4}$ Department of Earth and Environmental Sciences, Bu- Ali Sina University, Hamedan, Iran.

*email: zahra.mohammadi@kuleuven.be

Mail to: rudy.swennen@kuleuven.be

\begin{abstract}
A travertine fissure ridge and travertine mound are situated $\sim 800 \mathrm{~m}$ from each other at the western margin of the active tectono-volcanic Sanandaj-Sirjan zone (western Iran). Despite their close proximity, the two geobodies show a difference in morphology, lithofacies, lithotypes, diagenesis and geochemistry. Petrographic analysis of the fissure ridge carbonates revealed homogeneous sparitic fabrics with dendritic structures reflecting precipitation under fast-flowing conditions from calcite supersaturated spring water. The mound carbonates are much more heterogeneous and display dominantly micritic fabrics with (mainly volcanic) clasts reflecting a lower energy flow regime and lower calcite saturation. In contrast to the limited diagenetic overprint of the fissure ridge carbonates, the more porous mound carbonates are affected by dissolution, cementation, and formation of $\mathrm{Mn} / \mathrm{Fe}$ oxide/hydroxides, attesting of a strong control on porosity by early diagenetic processes. The widespread bright luminescent calcite phases especially in sparitic fabrics within both geobodies display high Mn concentrations in calcite indicating suboxic precipitation conditions.
\end{abstract}


The overlapping ${ }^{87} \mathrm{Sr} /{ }^{86} \mathrm{Sr}$ signatures and $\delta^{13} \mathrm{C}$ signatures point to a mixture of $\mathrm{CO}_{2}$ that dominantly originated from dissolution of the marine carbonate Qom Formation (Oligo-Miocene). The different $\delta^{18} \mathrm{O}$ signatures, indicate different upwelling systems caused by different substrate settings. The fissure ridge formed on a hard and brittle limestone substrate with precipitation from dominantly subsurfacesourced fluids. The mound travertine formed on top of fairly unconsolidated and fractured volcanic strata. The depleted $\delta^{18} \mathrm{O}$ signatures and impure micrite-dominated fabrics of the mound travertine reflect precipitation from thermal water that mixed with surrounding groundwater. This difference is also reflected in a different calculated precipitation temperature, that varies between $4-21^{\circ} \mathrm{C}$ for the mound versus $25-50^{\circ} \mathrm{C}$ for the fissure ridge.

Our findings show that subsurface geology exerts a major control on precipitation processes resulting in differences in travertine morphology, sedimentology, diagenesis, and geochemistry, despite that the travertine bodies occur adjacent to each other.

Keywords: Travertine, Fissure ridge, Mound, Substrate, Geobody, Sanandaj-Sirjan zone

\section{Introduction}

Tufa and travertine (sensu Capezzuoli et al., 2014) form from emerging calcium and bicarbonate enriched spring waters (e.g. Guo and Riding, 1992, 1994, 1998; Pentecost and Viles, 1994; Ford and Pedley, 1996; Pentecost, 2005). Different types of travertine geobody architectures are known such as waterfalls, mounds, fissure ridges and/or terrace mounds (e.g. Chafetz and Folk, 1984; Pentecost, 2005; Jones and Renaut, 2010; Fouke, 2011). These morphological variations are controlled by a variety of regional and local factors such as topography, tectonic setting as well as volcanic activity, substrate lithology, vent location characteristics and discharge rates, flow paths and physico-chemical properties of the spring water (e.g. Chafetz and Folk, 1984; Altunel and Hancock, 1993a, b; Özkul et al., 2002; Pentecost, 2005; Della Porta, 2015).

Mound spring and fissure ridge geobodies are reported to form economically important hydrocarbonbearing successions within the Pre-Salt Play (offshore Brazil; Sharp et al., 2013) and Angola (Carminatti et al., 2008). Therefore, a detailed study of analogue outcrops potentially helps to constrain 
controls on reservoir characteristics. Several travertine analogue studies have been published recently (e.g. Ronchi and Cruciani, 2015; Soete et al., 2015; De Boever et al., 2016; Claes et al., 2017a,b; Erthal et al., 2017; Török et al., 2017; Mohammadi et al., 2019). In general, fissure ridge geobodies have been studied by many authors, especially in terms of morphotectonic features and their connection to brittle structures (e.g. Guo and Riding, 1999; Hancock et al., 1999; Uysal et al., 2007, 2009; Brogi and Capezzuoli, 2009, 2014; Temiz and Eikenberg, 2011; De Filippis et al., 2012, 2013; Berardi et al., 2016). In addition, mound structures (Akdim and Julia, 2005, Pentecost, 2005; Pedley, 2009) were studied elsewhere in the world (e.g. Crombie et al., 1997; Linares et al., 2010, Pola et al., 2014). Morphology of mound spring and fissure ridge travertine geobodies overlying extensional fracture systems were reported to be related to substrate geology (Hancock et al., 1999). However, to the best of our knowledge, no one reported on different geobody morphologies that occur adjacent to each other and where the importance of the geological substrate on geobody development has been addressed. With the Pre-Salt context in mind, this becomes even more interesting when such geobodies are located in an area with volcanic rocks, as addressed by Lottaroli et al. (2012), Sharp et al. (2012), Wright, (2012), Teboul et al. (2017) and Eustáquio Moreira Lima and De Ros (2019). Additionally, mineralogy and geochemistry of travertine rocks are sensitive to particular environmental conditions in which they form (e.g. Hancock et al., 1999; Andrews, 2006; Keppel et al., 2011). Consequently, detailed analysis of these, often heterogeneous, carbonate build-ups can help to better constrain the factors controlling relevant properties such as the depositional setting, lithotype, diagenesis, and palaeoenvironmental reconstruction.

Travertines are common in Iran with more than 200 sites being reported and documented based on geological mapping by the Iranian Geological Survey. In the Hamadan-Tabriz volcanic (HTV) arc (Sanandaj-Sirjan zone in western Iran; Fig. 1), several travertine geobodies occur. The dominant morphologies are fissure ridges and spring mounds. In the study area named Babagorgor, representative fissure ridge and spring mound were selected for this study. Both are located at $\sim 800 \mathrm{~m}$ from each other and occur adjacent to basalt and andesite volcanics, limestones and alluvial-fluvial deposits. These morphologically different travertines can be important archives with regard to the controlling 
parameters that gave rise to these geobodies. Despite that some studies provided important insights into the nature and types of volcanism in the study area (Sepahi and Athari, 2006; Azizi and Jahangiri, 2008; Azizi and Moinevaziri, 2009; Razavi and Sayyareh, 2010; Azizi et al., 2013), structural geology (Mohajjel et al., 2003; Ghasemi and Talbot, 2006) and some overall knowledge on the petrography and stable isotope geochemistry of the HTV travertines recently became available (Roshanak et al., 2018), very little information about the interplay between geological setting, sedimentology, diagenesis and geochemistry is known about these travertine deposits. Consequently, this study provides a detailed characterization of the mound and fissure ridge carbonates including variation and contrast in geobody architecture, fabrics, diagenesis and geochemistry in order to address the controlling factors.

\section{Geological setting}

The Iranian plateau is part of the Alpine-Himalayan orogenic belt and is divided into eight main structural zones separated by deep faults (Stocklin, 1968) (Fig. 1). The Sanandaj-Sirjan Zone (SSZ) is a region testifying of a polyphase deformation on the southwestern margin of Eurasia (Hassanzadeh and Wernicke, 2016). This structural zone, situated in western Iran, relates to the northward motion of the Arabian platform (Zagros Fold Belt) during the Mesozoic and early Cenozoic, caused by subduction of the Neo-Tethys oceanic lithosphere under Eurasia (Frizon de Lamotte et al., 2011). Based on the presence or absence of volcanic activity, this zone is divided into a southern and northern part. In the northern part, named Hamamadan Tabriz Volcanic belt (HTV), which is of relevance for this study, active volcanism took place during the Early Miocene till Quaternary (Okay et al., 2010) (Fig. 1). Based on age, morphology and rock type, the volcanic deposits in the HTV are characterized by Miocene intermediate to acidic volcanic rocks and Plio-Quaternary basaltic rocks (Boccaletti et al., 1976; Hosseiny, 1999; Richards et al., 2006; Azizi et al., 2014) (Fig. 1). According to Richards et al. (2006) and Malecootyan et al. (2007), the Quaternary alkali basalts originated from an OIB-type source mantle testifying of an extensional tectonic regime, following the late Miocene collision of the Arabian and Iranian plates. Oceanic plate rollback and mantle upwelling after the Miocene collision are considered to be responsible for the extensional regime in the northern SSZ (Azizi et al., 2013). 
Besides different kinds of volcanic, metamorphic and sedimentary rocks, tens of kilometres of fossil travertines together with active geothermal systems are present in HTV. Close to the city of Ghorveh, the travertine system is still active showing spring related precipitation. The widespread formation of travertine is considered to reflect post-volcanic and tectonic activity within the area. The spatial distribution of the travertine deposits is scattered and the size of the individual travertine occurrences varies from few $\mathrm{m}^{2}$ up to $\mathrm{km}^{2}$ (Fig. 1C). Based on Geological Survey of Iran, the following formations occur in the study area:

- Quaternary sedimentary-igneous rocks consisting of alluvial sediments, travertines, poorlyconsolidated conglomerates, basanites and basalts.

- Pliocene sedimentary-igneous rocks composed of argillaceous limestones, marls, sandy marls, conglomerates, together with tuffs, lapilli/pumiceous tuff breccias, lahars, latites, dacites and clays.

- Late Miocene conglomerates, calcareous sandstones and evaporites (Upper Red Formation).

- Oligocene-Miocene reefal and chalky limestones, as well as fossiliferous (especially corals) limestones and evaporites (Qom Formation).

- Eocene conglomerates, calcareous sandstones and evaporites (Lower Red Formation).

- Triassic-Jurassic sedimentary-metamorphic rocks composed of quartzites, micaschists, phyllites, slates, (crystalline) limestones, breccias and marbles.

- Triassic metamorphic rocks consisting of meta-andesites, amphibolites, black schists, phyllites, metagabbros and scapolite marbles.

The studied area, called Babagorgor, is located between $47^{\circ} 32^{\prime}$ and $48^{\circ} 11^{\prime} \mathrm{E}$ and $35^{\circ} 05^{\prime}$ and $35^{\circ} 30^{\prime} \mathrm{N}$, about $6 \mathrm{~km} \mathrm{NE}$ of Ghorveh county in Kurdistan province, western Iran. The Quaternary Babagorgor travertine occurrence consists of dominantly inactive spring pipes, spring mounds and fissure ridges (Fig. 1D). For this study, respectively the largest neighbouring mound and fissure ridge deposit, of which the main springs are no longer active as well as two adjacent small travertine springs have been sampled for a detailed sedimentological, diagenetical and geochemical study. 


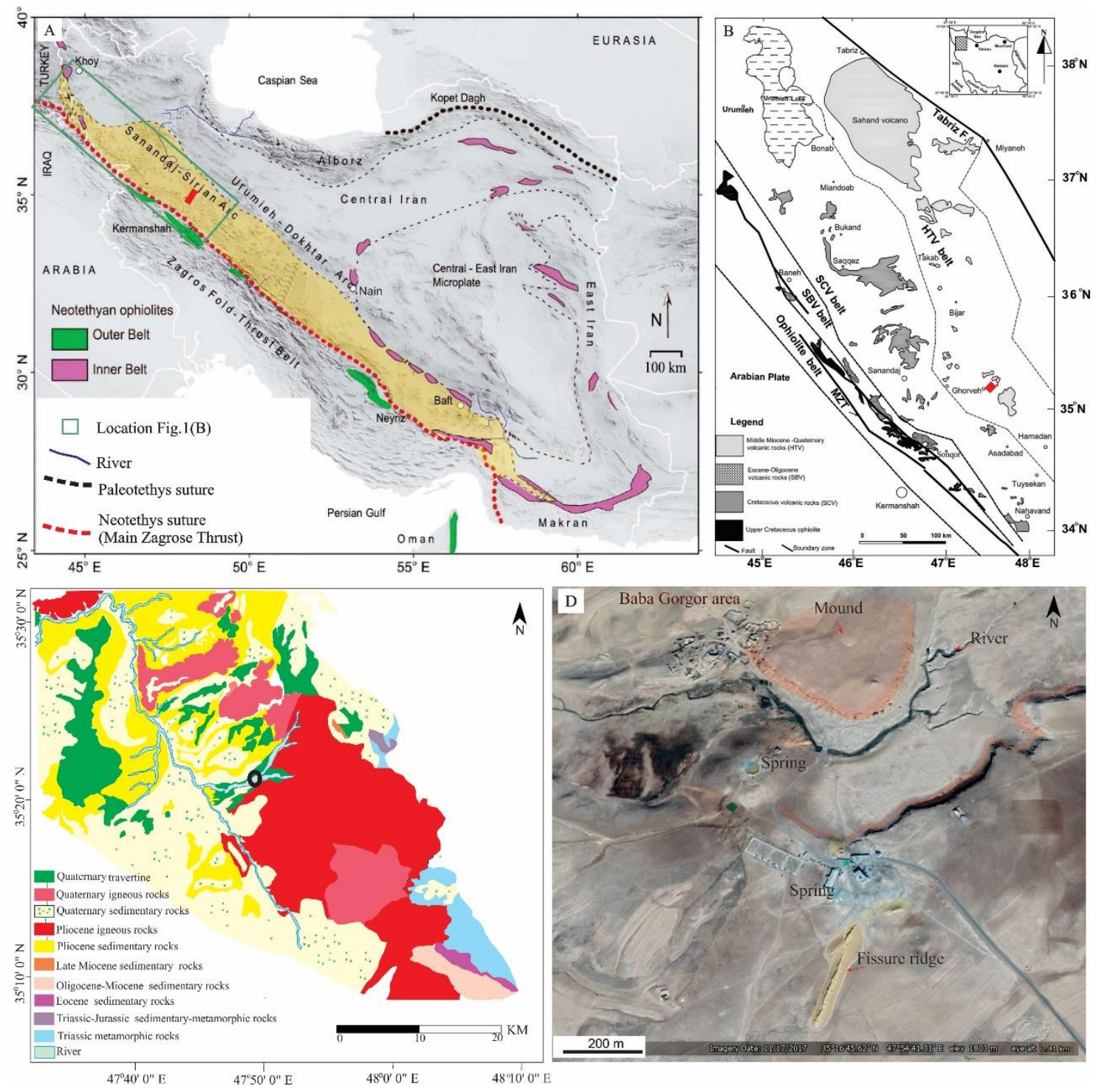

Fig. 1. A) Simplified geological map of the Iranian plateau with eight main structural zones (modified after Hassanzadeh and Wernicke, 2016). The green rectangle (in the northwestern part of the picture) shows the position of the map in B. B) Geological map of the Hamadan-Tabriz volcanic belt (HTV) characterized by young volcanics (Azizi and Moinevaziri, 2009) where the small red rectangle shows the location of the study area. C) Simplified geological map of the study area (after Geological Survey of Iran and Karimi Nezhad et al., 2014). The black circle is where the mound and fissure ridge are situated. D) Google earth image of the Babagorgor area. Reddish colour shows mound and related travertine sediments. Yellowish colour displays the main fissure ridge together with some detached parasitic fissures and the blueish colour represents nearby active springs.

\section{Methodology}


Fieldwork was carried out in April and September 2017. A detailed macroscopic mapping and description was followed by a representative sampling of the main lithologies of both fissure ridge and mound structure (Fig. 1D). Microscopic analysis of epoxy impregnated (containing a fluorescent dye) thin sections by the use of an Olympus BX60 and Leica DM LP Parallel and Crossed Polar Optical as well as Fluorescence microscope (respectively abbreviated as TL, PL and FL) and Cathodoluminescence (CL: using a modified Technosyn 8200MK2 instrument at $10 \mathrm{kV}$ and $300-400$ $\mu \mathrm{A}$ gun current) led to the characterization of macro- and microfacies, as well as the identification of the diagenetic processes. Bulk samples for major and trace elements (e.g. $\mathrm{Ca}, \mathrm{Mg}, \mathrm{Fe}, \mathrm{Mn}, \mathrm{Na}, \mathrm{Sr}$ ) were analysed at the KU Leuven by ICP-OES. A four acids digestion of the samples consisted of $\mathrm{HNO}_{3}(14 \mathrm{M}$ or $65 \%$, sub-boiled), $\mathrm{HClO}_{4}$ (70\%, pro analysis Sigma Aldrich), $\mathrm{HF}$ (49\%, sub-boiled) and $\mathrm{HCl}(2.5 \mathrm{M})$. The procedure for major and trace element analysis is the same as reported in Mohammadi et al. (2019). Stable carbon and oxygen isotopes of sparite and micrite which were prepared by micromilling allowed to enhance the accuracy of measurements. The latter were analysed at KU Leuven on a Thermo Delta V Advantage isotope ratio mass spectrometer coupled to a GasBench II. In the laboratory, samples were flushed with helium and reacted with $100 \%$ phosphoric acid to produce $\mathrm{CO}_{2}$ gas. Samples were allowed to react for 24 hours at $25^{\circ} \mathrm{C}$ to reach isotopic equilibrium. Data from each run were corrected using the regression method with LSVEC $\left(\delta^{18} \mathrm{O}=-26.7 \%\right.$, $\left.\delta^{13} \mathrm{C}=-46.6 \%\right)$, NBS-19 $\left(\delta^{18} \mathrm{O}=-5.01 \%\right.$, $\delta^{13} \mathrm{C}=$ $-23.2 \%)$, and NBS-19 $\left(\delta^{18} \mathrm{O}=-2.2 \%, \delta^{13} \mathrm{C}=+1.95 \%\right)$ as standards, as well as using two in-house $\mathrm{CaCO}_{3}$ standards, which were regularly calibrated against NBS-19 and LSVEC. Long-term standard deviations were better than $0.1 \%$. Both $\delta^{18} \mathrm{O}$ and $\delta^{13} \mathrm{C}$ values of samples are expressed relative to $\mathrm{V}$ PDB (Vienna Pee Dee Belemnite). For strontium isotope analysis, powdered carbonate samples were digested in $2.5 \mathrm{M} \mathrm{HCl}$ after being leached in $1 \mathrm{M} \mathrm{NH}_{4} \mathrm{Ac}$. The $\mathrm{Sr}$ fraction was separated from the matrix into 2.5 M HCl with a Bio-Rad AG50WX8 200-400 mesh cation exchange resin, which is Sr-selective. Prior to mass spectrometrical analysis with a VG Sector 54-30 multi-collector MS, the sample was loaded on Ta-filaments with $1 \mathrm{M} \mathrm{H}_{3} \mathrm{PO}_{4} . \mathrm{A}^{88} \mathrm{Sr}$ intensity of $1 \mathrm{~V}(1 \mathrm{x} 10-10 \mathrm{~A}) \pm 10 \%$ was maintained throughout the measurement. Correction of the ${ }^{87} \mathrm{Sr} /{ }^{86} \mathrm{Sr}$ ratio for mass fractionation is realised by applying Russel's law and the invariant ${ }^{86} \mathrm{Sr} /{ }^{88} \mathrm{Sr}$ ratio of 0.1194 (Steiger and Jäger, 1977). FEG EPMA of polished thin sections with a Jeol JXA8530F instrument, using energy dispersive spectrometer (EDS) 
mode (for spot analysis) and wavelength dispersive spectrometer mode (WDS) (in mapping mode) was also carried out at KU Leuven.

In this study, the lithotype terminology is based on previously published classifications of travertine (Chafetz and Folk, 1984; Guo and Riding, 1998; Della Porta, 2015; Claes et al., 2015; Croci et al., 2016; Mohammadi et al., 2019) and on the Dunham (1962) and Embry and Klovan (1971) classification for carbonate depositional texture. The term crystalline dendrite refers to layers made up of precipitated calcite crystals, previously labelled as ray crystalline shrubs by Folk et al. (1985), crystalline crusts by Guo and Riding (1998), crystal shrubs by Chafetz and Guidry (1999), shrubby boundstone by Saller et al. (2016) and fascicular calcite crusts by Herlinger et al. (2017).

For water samples, the selected springs were sampled at the vent. In the field, $\mathrm{pH}$ and water temperature were measured with a portable probe, Cond340i. Water samples for $\delta^{18} \mathrm{O}$ analysis were collected in 12 $\mathrm{ml}$ Labco exetainer vials and were measured by equilibration with $\mathrm{CO}_{2}$ using an Elemental Analyzer Flash HT coupled to a ThermoFinningan Delta V Advantage isotope ratio mass spectrometer (EAIRMS) (described in Gillikin and Bouillon, 2007). Water samples for $\delta^{13} \mathrm{C}$ isotopic composition of dissolved inorganic carbon $\left(\delta^{13} \mathrm{C}_{\mathrm{DIC}}\right)$ were collected by filling water directly in $12 \mathrm{~mL}$ Niskin headspace vials (Labco Exetainer) without bubbles. An additional $20 \mu \mathrm{L}$ of a saturated $\mathrm{HgCl}_{2}$ solution was added for sample preservation. Prior to the analysis of $\delta^{13} \mathrm{C}_{\mathrm{DIC}}$, a $2 \mathrm{~mL}$ helium headspace was created, and 100 $\mu \mathrm{L}$ of phosphoric acid $\left(99 \% \mathrm{H}_{3} \mathrm{PO}_{4}\right)$ was added in the vial in order to convert all inorganic $\mathrm{C}$ species to $\mathrm{CO}_{2}$. After overnight equilibration, $200 \mu \mathrm{L}$ of gas was injected with a gastight syringe into an elemental analyzer - isotopic ratio mass spectrometer (EA-IRMS; Thermo FlashHT with Thermo DeltaV Advantage). The obtained data were corrected for isotopic equilibration between dissolved and gaseous $\mathrm{CO}_{2}$ as described in Gillikin and Bouillon (2007). Calibration of $\delta^{13} \mathrm{C}_{\text {DIC }}$ measurement was performed based on the international certified standards IAEA-CO1 and LSVEC. The reproducibility of $\delta^{13} \mathrm{C}_{\text {DIC }}$ measurement was typically better than $\pm 0.2 \%$.

Measurements of total alkalinity (TA) were carried out by open-cell titration with $\mathrm{HCl} 0.1 \mathrm{~mol} \mathrm{~L}^{-1}$ according to Gran (1952) on $50 \mathrm{~mL}$ water samples, and data were quality checked with a certified reference material obtained from Andrew Dickinson (Scripps Institution of Oceanography, University 
of California, San Diego, USA). Typical reproducibility of TA measurements was better than $\pm 3 \mu \mathrm{mol}$ $\mathrm{L}^{-1}$.

\section{Results and interpretation}

\subsection{Morphological description}

According to the definition of Altunel and Hancock (1996), a fissure ridge geobody is a linear elongated travertine structure deposited from underground circulating hot waters which is characterized by a central extensional fracture extending along the crest of the ridge for nearly its entire length, often with associated minor subparallel fractures, i.e. parasitic fractures. The main property of the studied fissure ridge relates to its symmetrical characteristics with same ridge height at opposite sides of the fissure with equal crust thicknesses, content, and distribution. The steeply sloping sides typically show microterracettes. The studied fissure ridge is about $120 \mathrm{~m}$ long and 6-8 $\mathrm{m}$ wide, with a height of 6-8 $\mathrm{m}$ (Fig. 2 and 3). It has a main SSW-NNE orientation. The fissure at the ridge crest shows today a maximum opening of $20 \mathrm{~cm}$. Parasitic fissures of $10 \mathrm{~m}$ length and with the same thickness, height and contents as the main fissure are attached to the latter. From crest to flanks, the inclination of the ridge starts from almost horizontal evolving to $70^{\circ}$ forming a steep slope and further evolving into a gentle slope of $10^{\circ}$. The flanks of the ridge show well-layered strata of varying thicknesses ranging between 0.5 to $5 \mathrm{~cm}$ with (palaeo)morphologies corresponding to both steep slope facies and smooth slope facies with micro-terraces, both consisting of crystalline dendrite crusts. The central part, which is closest to the fissure, corresponds to the highest elevation and is composed of sub-horizontal facies consisting of intercalations of micritic laminites and encrusted bubbles with banded travertine deposits. 

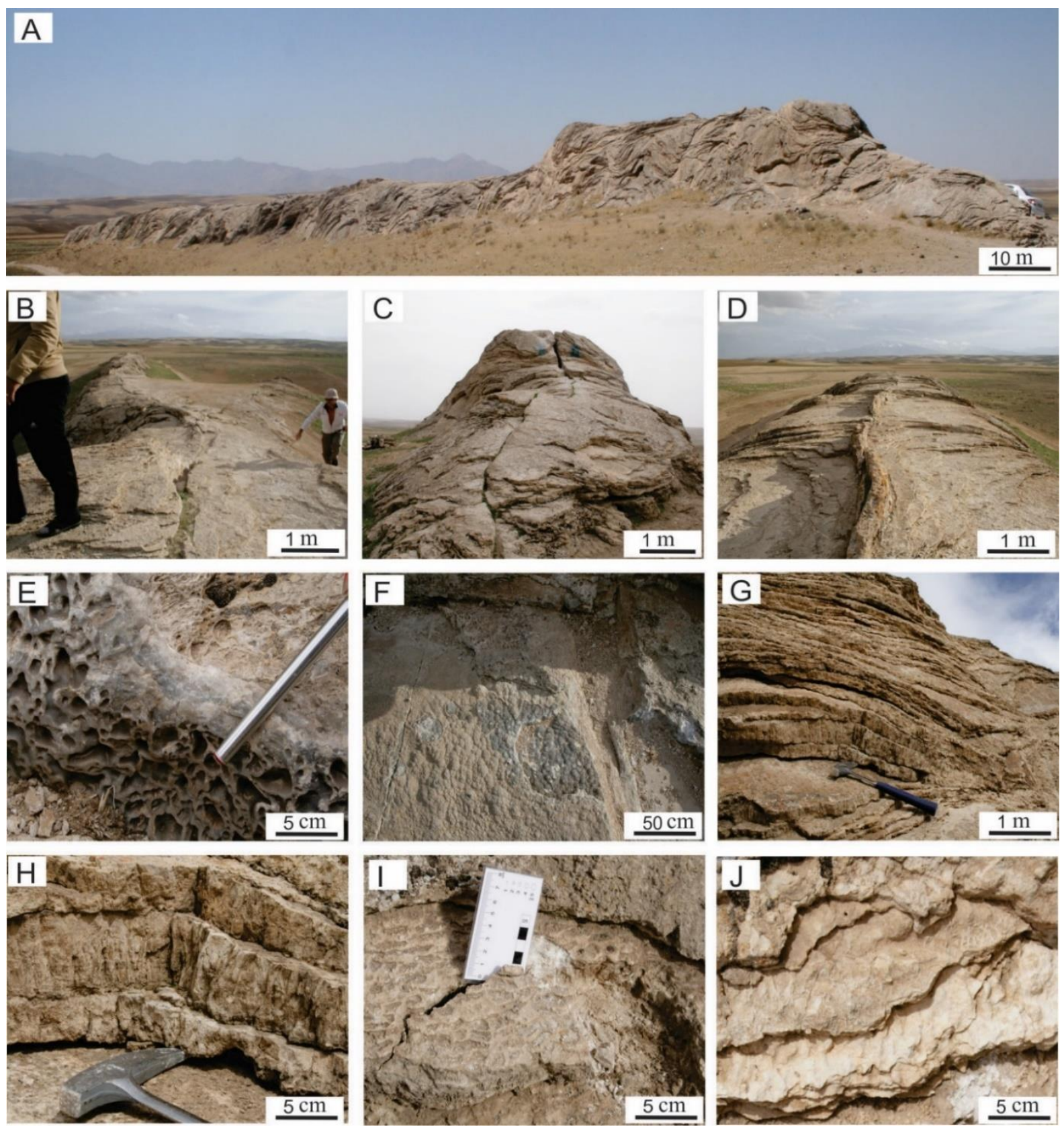

Fig. 2. A) View on the fissure ridge geobody. B and C) Main fracture visible at the top of the fissure ridge. D) Centimetre-thick layers of banded travertine growth inside the main fracture intercalated with micritic laminites. E) Outcrop photo from banded travertine growth inside the main fracture. F) Close up view of banded travertine growth perpendicular to fissure ridge layer. G) Overview of different wavy laminae present along the ridge slope. H) Close up view of laminae with straight branching dendritic crystal structure. I) Micro-terracettes of laminae. J) Close up view of thin laminae at the edge of the ridge. 


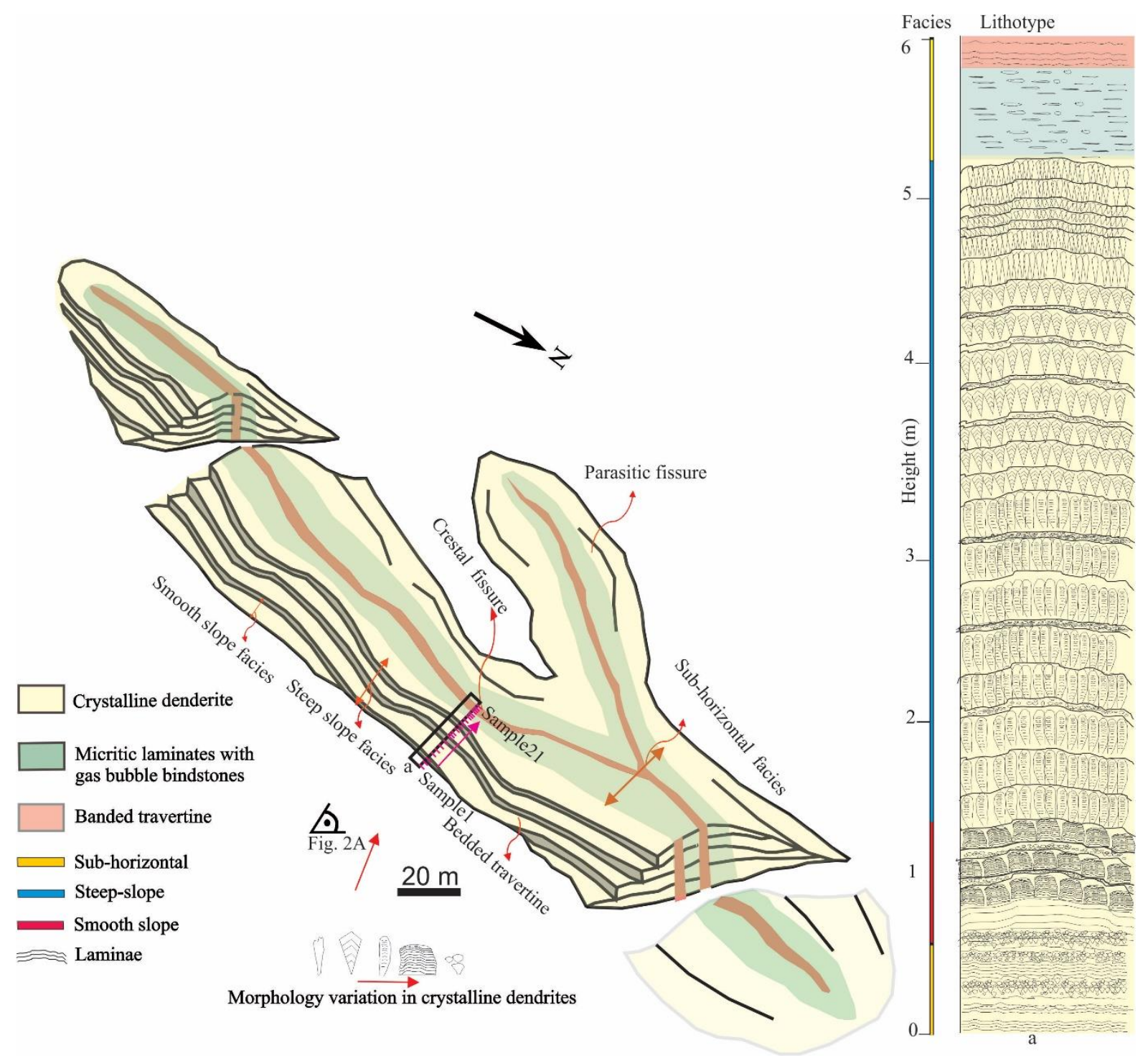

Fig. 3. Schematic illustration of the morphology (left) and log (right) of the different facies and layers of the fissure ridge. The log location is indicated with a vertical black rectangle along the ridge.

The mound spring is defined according to Williams and Holmes (1978), Pentecost and Viles (1994), Crombie et al. (1997) and Linares et al. (2010). It displays a prominent dome-shaped structure. The studied mound travertine structure has a height of about $15 \mathrm{~m}$ and is about $500 \mathrm{~m}$ in diameter with circular and pipe-like orifice shapes. Mound profiles reflect smooth slope-sides of $20^{\circ}$ that laterally evolve into horizontal tails. The spring mound system (Fig. 4) is composed of light and dark coloured laminae with some horizontal calcite veins. In some cases, travertine interlayers are stained by $\mathrm{Mn} / \mathrm{Fe}-$ oxide/hydroxides. Layers are often crosscut by vertical unfilled fractures, which relate to postdepositional gravitational sliding. 

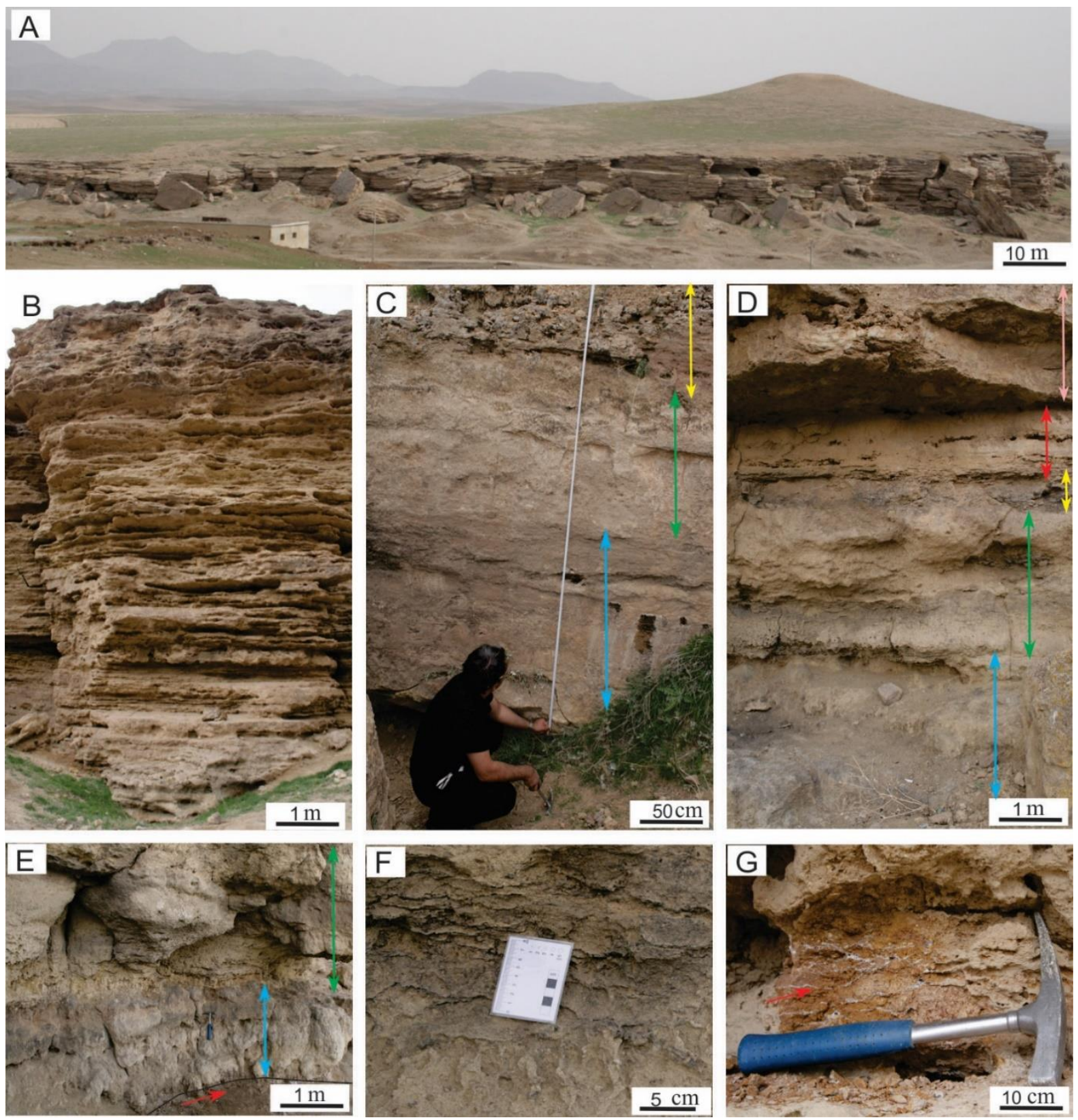

Fig. 4. Field photographs illustrating the mound travertine stratal patterns. A) Overview of the mound geobody. B) Overview of travertine laminae in the proximal part of the mound. C) Dark, thick and packed laminae (blue arrow) evolving into light, thick laminae with fenestral-like porosity (green arrow) passing into poorly unconsolidated laminae (yellow arrow). D) Laminited succession of $\mathrm{Mn} / \mathrm{Fe}-$ oxide/hydroxides stained mudstone (blue arrow) evolving into silty mudstone (green arrow), algal mudstone (yellow arrow), cementstone (red arrow) and ending in compact coated reed and coated grass laminae (orange arrow). E) Contact of travertine with underlying volcanic unit (tuff; red arrow), $\mathrm{Mn} / \mathrm{Fe}-$ 
oxide/hydroxides stained laminae (blue arrow) and silty mudstone (green arrow). F) Close up view of silty mudstone. G) Cement (red arrow) incorporation within unconsolidated travertine laminae.

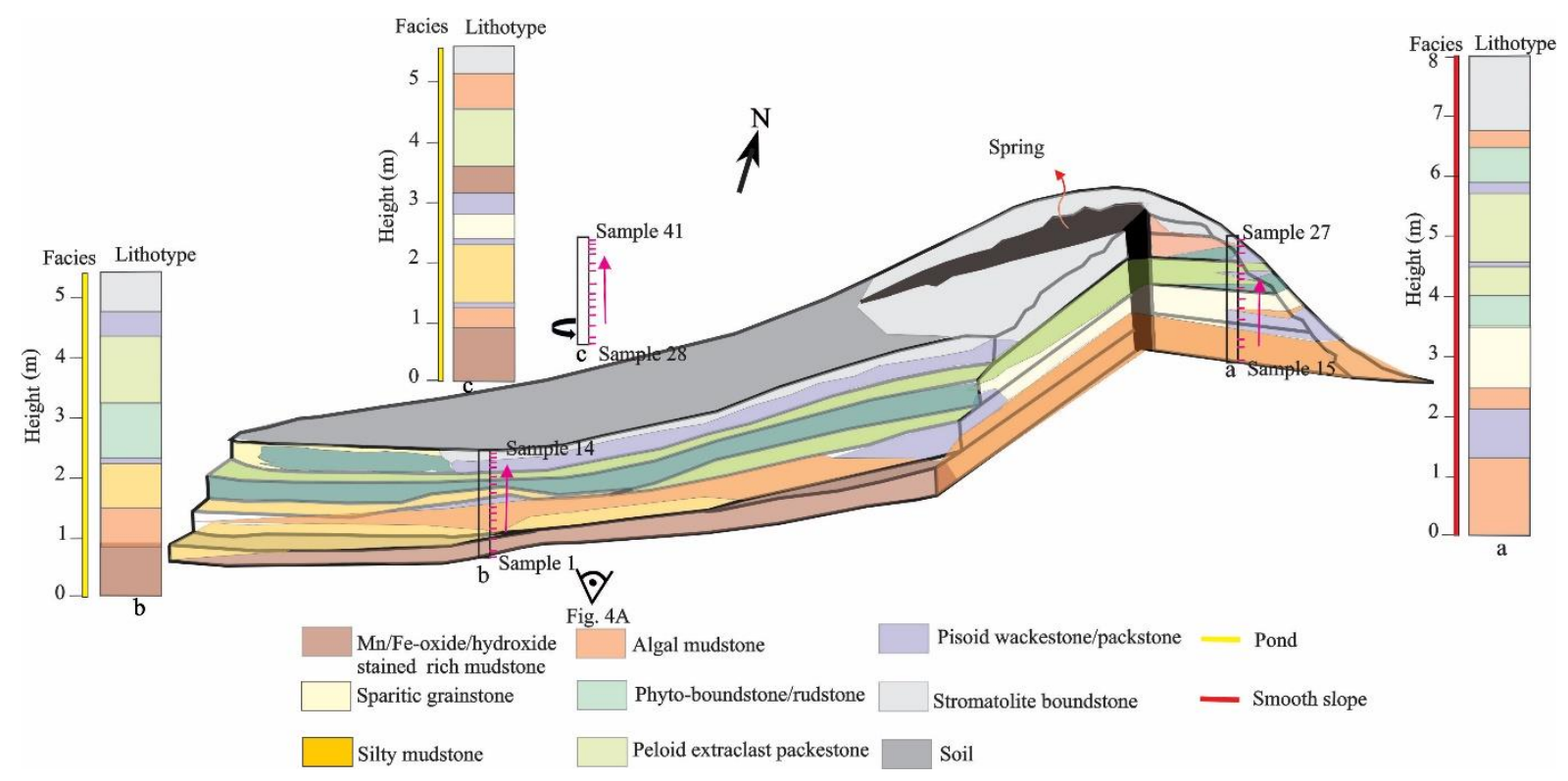

Fig. 5. Schematic drawing and logs illustrating the lithological variation within the mound structure.

Log locations are indicated with rectangular lines in morphology.

\subsection{Petrography and mineralogy}

Fifteen samples were analysed by XRD indicating that the fissure ridge carbonates consists of $97 \%$ calcite, while the mound lithology contains on average $80 \%$ calcite and $20 \%$ detritals especially clay minerals, together with quartz, volcanic clasts (e.g. containing pyroxenes, plagioclase and muscovite) and $\mathrm{Fe} / \mathrm{Mn}$-oxide/hydroxides (as can also be inferred from the geochemical analysis).

\subsubsection{Lithotypes of the fissure ridge}

The fissure ridge geobody is made up by three lithotypes including crystalline dendrite, banded travertine and micritic laminite bindstones with gas bubbles. The first lithotype makes up $>80 \%$ of the fissure ridge and the others are restricted to $<20 \%$ and only occur near the fissure.

Crystalline dendrite is macroscopically characterized by straight branching feather-like crystals oriented perpendicular to their substrate. Maximum crystal size is $3 \mathrm{~cm}$ in length and $1 \mathrm{~cm}$ in width. Within the crystals an alternation of thin elongated darker and lighter colours can be recognized. This 
lithofacies laterally develops in almost all layers of steep and smooth slope micro-terrace lithologies. Microscopically almost pure calcite occurs which is made up of sparitic tight prismatic coarse crystals (up to $3 \mathrm{~cm}$ ) with dendritic shapes. They display a branching with curved or triangle-shaped terminations. The terminations between two bands consist of a dark layer of variable thickness which is composed of sub-rounded clumps of micritic or fine-crystalline calcite. Depending on where sparitic crystals precipitated, they show a variety of textures (e.g. morphologies and crystal sizes) (Fig. 6N). Those which precipitated along steep slopes represent sharp dendritic profiles with steeply triangular crests (Fig. 6C). Those that formed in smooth slope settings have more undulating domal shapes with gently convex features (Fig. 6D and E). The ones which formed in smooth slope to sub-horizontal layers consist of stratiform crenulated to sub-regular laminae (Fig. 6F). Inside each lamina several sub-laminae of thick sparite and thin micrite occurs (Fig. 6D to H). These sub-laminae possess thick sparitic and thin micritic parts in the stepped slope, while, in smooth slope to sub-horizontal settings, sparite thickness decreases and micritic laminae thickness increases. The lowest part of the fissure ridge, which consists of nearly horizontal layers, possesses rounded to sub-rounded crystals (Fig. 6I). All laminae show a bright luminescence with zoned pattern. The thin darker luminescent zones display high micro-porosity (Fig. 6G and H). This lithotype is comparable to the ray crystalline shrubs of Folk et al. (1985), calcite feathers crystals (Guo and Riding, 1992, 1998; Gandin and Capezzuoli, 2014), and dendrite crystals (Jones and Renaut, 1995) crystal shrubs of Chafetz and Guidry (1999).

Banded travertine crusts appear as glossy laminae within dark and light-coloured bands that developed in the central fracture. In some cases, they form vertical pipe structures consisting of two symmetrical crusts. The thickness of the crusts ranges from 1 to $50 \mathrm{~cm}$ and are laterally semi-continuous along the entire length of the fissure (about $120 \mathrm{~m}$ ). They are distinguishable from micritic laminite bindstones by their sharp boundary and distinct difference in crystal shape (Fig. $6 \mathrm{~J}$ and $\mathrm{K}$ ). Microscopically, the banded travertine crusts show a vertical alternation of micron-sized dark micritic laminae and millimetre-sized sparitic laminae of fibrous calcite (Fig. 6L). They show the same bright luminescence as the previous lithotype, but without microporous dull luminescent zones. This lithotype 
is also described as 'banded travertine' by Altunel and Hancock (1993a,b; 1996), Özkul et al. (2002) and Gandin and Capezzuoli (2014).

Micritic laminites with gas bubble bindstones: macroscopically these bindstones consist of micritic laminae with intercalated coated bubbles. They commonly are associated with banded travertine (see Fig. $6 \mathrm{~J}$ and $\mathrm{K}$ ). They are well developed on top of the fissure ridge where they form sub-horizontal layers. Microscopically, the coated bubbles are embedded in two micrite layers with or without cement (Fig. 6M). In most of the study area they show a bright orange luminescence together with randomly distributed dull luminescent parts. 

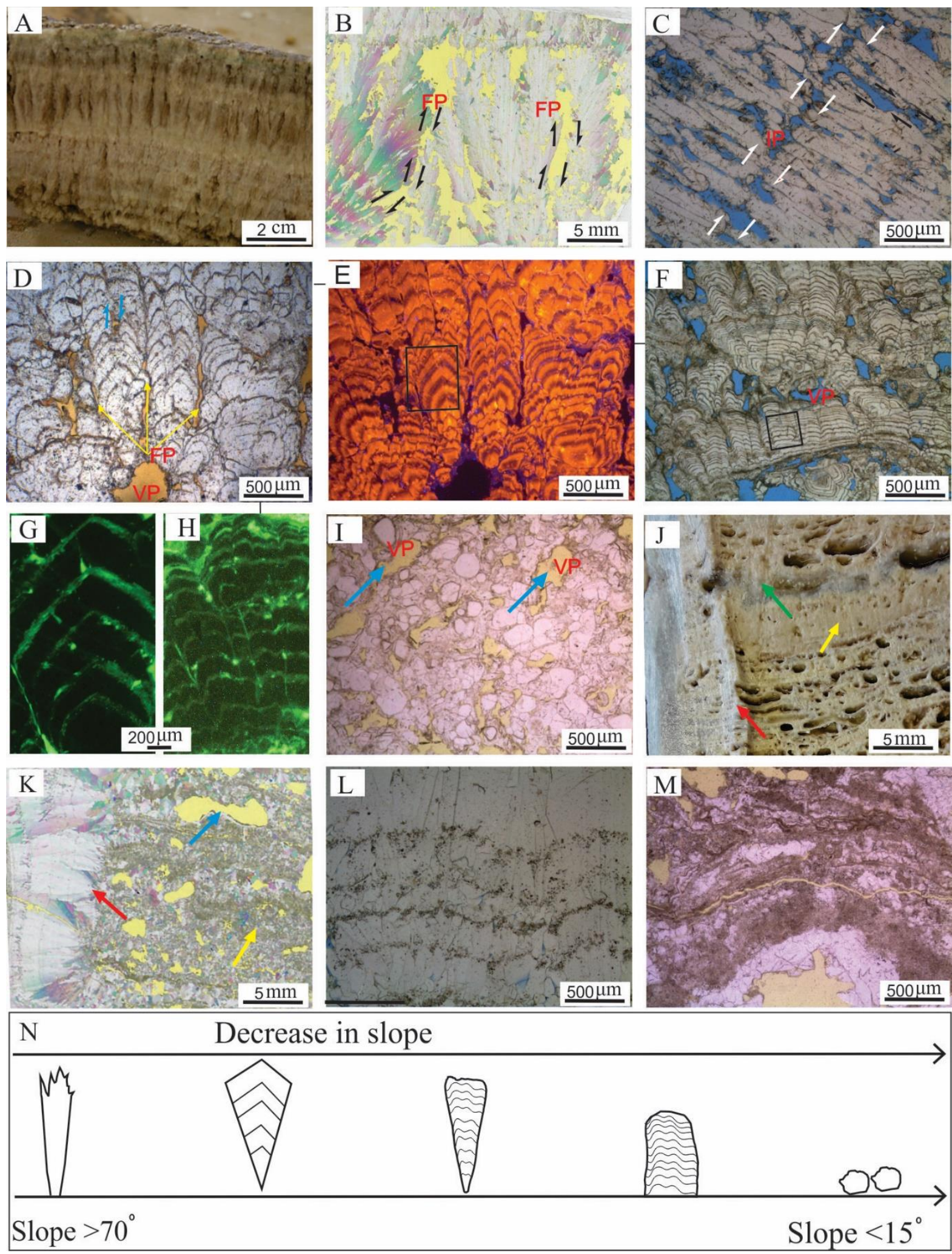

Fig. 6. Microphotographs (transmitted light TL, polarizing light PL, cathodoluminescence CL and fluorescence light FL) illustrating the different lithotypes of the fissure ridge (abbreviations: IP = interlayer porosity; $\mathrm{FP}=$ framework porosity; $\mathrm{VP}=$ vug porosity; pores are yellow coloured in $\mathrm{B}, \mathrm{D}, \mathrm{K}$ 
and $\mathrm{M}$, blue coloured in $\mathrm{C}$ and $\mathrm{F}$ and green coloured in $\mathrm{G}$ and $\mathrm{H}$ ). (A) Hand sample photograph of straight branching feather-like crystals of dendritic shrubs. (B) Thin section scan (PL) of a subsample from (A). (C) Straight and narrow branching feather-like dendritic crystalline dendrites (TL). The white arrows show the border between two layers of crystalline dendrite. (D) Crystalline dendrite textures showing wavy and banded internal zonations (TL). (E) Bright orange - dull luminescent zones in (D), pores are black (CL). Black rectangle indicates the area of $(\mathrm{G})$. (F) Amalgamated crystalline dendrites together with cement without sharp dendritic structure. Black rectangle indicates the area of $H .(G)$ Bright fluorescence of micritic laminae of dendrite crystals in the area indicated with the black rectangle in $\mathrm{E}(\mathrm{FL})$. (H) Bright fluorescence in wavy zones of (F) (black rectangular) (FL). (I) Granular crystalline dendrite (PL). (J) Hand sample showing banded travertine (red arrow) and micritic laminite bindstones together with open bubbles (blue arrow) and cement in micritic laminite bindstones (green arrow). (K) Thin-section scan prepared from (J) showing radial-fibrous calcite (red arrow) developing on micritic laminae (yellow arrow) (PL). (L) Alternation of thin micrite and thick sparite laminae in banded travertine (TL). (M) Alternating micrite and sparite zones in micritic laminite bindstones with gas bubble (TL). (N) Morphology variation of crystalline dendrites as a function of steep to smooth slope position.

\subsubsection{Lithotypes of mound travertines}

In the mound geobody, eight lithotypes including $\mathrm{Mn} / \mathrm{Fe}$-oxide/hydroxide stained mudstone, algal mudstone, silty mudstone, peloid extraclast packstone, sparitic grainstone, phytoclast boundstone, pisoid wackestone/packstone and stromatolite boundstone can be differentiated.

Mn/Fe-oxide/hydroxide stained mudstone makes up dense dark to red coloured layers with thicknesses ranging from 20 to $80 \mathrm{~cm}$. This mudstone alternates laterally and vertically with algal mudstone. It always contains a network structure of $\mathrm{Mn} / \mathrm{Fe}$-oxide/hydroxides (Fig. 7A). Microscopically this lithotype consists of aggregates of dense micrite, organized in breccia-like pieces with some rare gastropods (Fig. 7B). Fracture and vug porosity which are partially filled first by $\mathrm{Mn} / \mathrm{Fe}-$ oxide/hydroxides and in the central part by equant sparite cement are widspread. The cement shows 
both dull and bright luminescence, while the mudstone is non-luminescent. A similar lithotype has been reported by Croci et al. (2016).

Algal mudstone makes up massive dark layers with a thickness ranging from 20 to $60 \mathrm{~cm}$. It alternates laterally and vertically with reed rudstone/boundstone and $\mathrm{Mn} / \mathrm{Fe}$-oxide/hydroxide stained mudstone. Microscopically it consists of aggregates of dense micrite with algal structures, structureless micrite with some gastropods and ostracods (Fig. 7C). It contains moldic and vuggy porosity that are entirely filled by dull luminecent equant sparite cement. This lithotype also displays some patchy $\mathrm{Mn} / \mathrm{Fe}$ oxide/hydroxide staining but in much lower concentration than in the previous lithotype.

Silty mudstone represents a compact, structureless, massive lithology with thick layers and light to grey colour (see Fig. 4F). This lithotype shows some variation in thickness from one centimetre in proximal parts up to one metre in thickness in the tail of the mound. It laterally shows vast extension in the tail. Microscopically, it displays silt-sized micrite with extraclasts which usually have a volcanic nature originating from surrounding volcanics. Some vuggy pores filled by calcite and/or $\mathrm{Mn} / \mathrm{Fe}-$ oxide/hydroxides also have been observed. Here the cement shows both dull and bright luminescence.

Peloid extraclast packstone consists of light-coloured layers of maximum $1 \mathrm{~m}$ in thickness. It is laterally well developed and shows a fenestral-like porosity. Microscopically, it consists of an aggregation of sub-rounded and irregular clotted micrite that occurs adjacent to volcanic fragments that are floating in a sparitic matrix (Fig. 7D and E). Blocky and equant cement fills up the interparticle porosity. It contains some detrital quartz and feldspar grains as well as lithic fragments and extraclasts. All carbonate phases display a bright luminescence (Fig. 7F). This lithotype is locally associated with pisoid wackestone/packstone.

Sparitic grainstone at macroscopic scale makes up centimetre thick laminae that are laterally continuous over tens of metres. The sparitic grainstone is often associated with peloid/extraclast grainstone and locally by phytoclast boundstone. Under the microscope this lithotype is composed of sub-rounded grains displaying pure sparitic fabrics with locally intergranular porosity (Fig. 7G). This 
porosity is entirely to partially filled by a cement possessing a dull luminescence, while the granular sparitic grainstone shows a bright luminescence (Fig. $7 \mathrm{H})$.

Phyto-boundstone/rudstone displays up to $50 \mathrm{~cm}$ sized, calcite coated hollow elongated in-situ and/or fragmented tubes (Fig. 7I). The thickness of this lithotype varies from centimetre to metre size. Laterally this lithotype can extend over more than ten metres. Under the microscope, clotted micrite surrounds the pores (Fig. 7J). These strata also contain some clay minerals. The main diagenetic feature of this lithotype is dissolution of organic material which produced a vast amount of moldic and framework porosity that locally are filled by an equant sparite cement with a bright orange luminescence. This lithotype has been reported from many Quaternary continental carbonate settings (e.g. Della Porta, 2015; Claes et al., 2015; Della Porta et al., 2017; Mohammadi et al., 2019).

Pisoid wackestone/packstone makes up compact laminae with a thickness ranging from 2 to $40 \mathrm{~cm}$. It alternates laterally and vertically with peloid extraclast packstone. Microscopically its constituents show highly diverse textures. The constituent cortex consists of several regular to wrinkly laminae with alternating crystal arrangements consisting of micrite, sparite and microsparite (Fig. 7K). Pisoid sizes vary from 0.4 to $2 \mathrm{~mm}$. These carbonates show moldic and interparticle porosity that usually are partially filled by equant to blocky cement with a bright orange luminescence. In some cases, some meniscus cement formed between pisoid grains.

Stromatolite boundstone displays fine lacy dark to light coloured laminae with a widespread cement between the laminae and some evidence of coated bubbles. The stromatolite boundstone formed at the top of the mound near the spring location, where this lithotype is laterally extended. The total thickness of this lithotype varies between 30 to $60 \mathrm{~cm}$. Microscopically it is composed of lacy conical micritic laminae occasionally covering bubble-like fabrics (Fig. 7L). They possess framework porosity that is partially filled by dull luminescent calcite or $\mathrm{Mn} / \mathrm{Fe}$-oxide/hydroxides. A similar lithotype has also been reported by Barth and Chafetz (2015). 

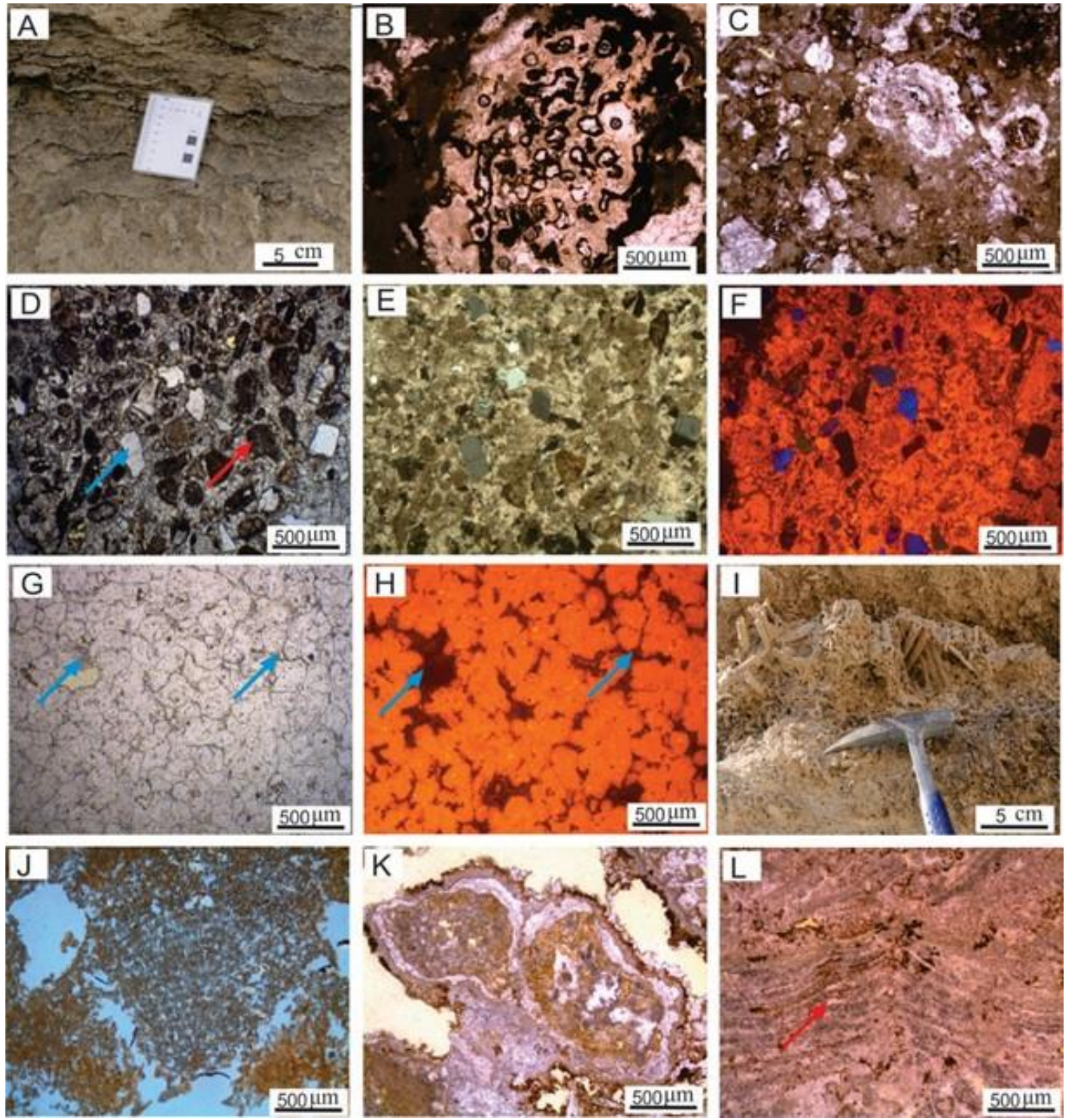

Fig. 7. Field and microphotographs (transmitted light (TL), polarizing light (PL) and cathodoluminescence (CL)) of different lithotypes from the mound spring geobody (porosity is yellow coloured in $\mathrm{G}$ and $\mathrm{K}$ and blue coloured in J). (A) Outcrop image of widespread $\mathrm{Mn} / \mathrm{Fe}$ oxide/hydroxide rich mudstone. (B) $\mathrm{Mn} / \mathrm{Fe}$ oxide/hydroxide stained mudstone (TL). (C) Calcite cemented algal mudstone (TL). (D-E) Amalgamation of peloids (red arrow) and volcanic fragments (blue arrow) (TL in $\mathrm{D}, \mathrm{PL}$ in $\mathrm{E}$ ). (F) Bright luminescent peloidal micritic components and matrix (CL), while the volcanic clasts do not luminescence. Blue grains are K-feldspars. Picture area identical to D. (G-H) Bright luminescent sparitic crystals and dull luminescent cement (blue arrow) (black areas in $\mathrm{H}$ are pores which 
are partialy to entirely filled by cement) (TL in G, CL in H). (I) Outcrop image of phyto rudstone and boundstone. (J) Phyto rudstone and boundstone (TL). (K) Pisoid wackestone. Pisoid displaying semiconcentric cortexes composed of sparite and micrite (TL). (L) Fine lacy stromatolite laminae boundstone. Red arrow indicates framework porosity (TL).

\subsubsection{Diagenesis and pore types}

Several diagenetic features have been observed, such as microporosity, micro- and macro-scale fracturing, micritization and cementation. The focus in this study lies on the differences of these features between the fissure ridge and mound geobody.

In general, diagenetic features are rare in the fissure ridge, but a zonation of bright and darker CL patterns (Fig. 8A and B) and a variety of pore types occur. The main pore type consists of interlayer porosity, which is horizontally semi-continuous between shrub laminae (see Fig. 6C) while framework porosity between the branches is vertically oriented (see Fig. 6D). It occurs together with a vuggy porosity usually separating granular shrubs (see Fig. 7I). Furthermore, micro-porosity, which developed along crystal boundaries (Fig. $8 \mathrm{C}$ ), is another widespread pore type in fissure ridge travertines. The aforementioned pores in the crystalline dendrite lithotypes are cemented.

In the mound geobody, the main diagenetic features consist of macro-scale unfilled fractures (mainly formed by gravitational sliding), recrystallization, micritization and cementation (Fig. 8A to O). Cements display mainly equant, scalenohedral and blocky habit that fill the pores partially to entirely (Fig. 8D to H). Macro- and micro-scale fractures are common, whereby macro-scale fractures are usually not cemented. Micro-scale fractures are cemented or open (Fig. 8I). Micritization partially affected sparitic fabrics and usually is dull luminescent in contrast to the original fabric that is orange luminescent (Fig. 8L). Recrystallization is also a common feature (Fig. 8M). The main pore types in the mound geobody consist of fenestral-like, interlayer, inter-particle, intra-particle and plant mouldic pores. The aforementioned pore types are partially to entirely filled by blocky cement ( 20 to $200 \mu \mathrm{m}$ in size) as well as by prismatic crystals (generally 0.1 to $1 \mathrm{~mm}$ in length), which show a bright and dull luminescence. 

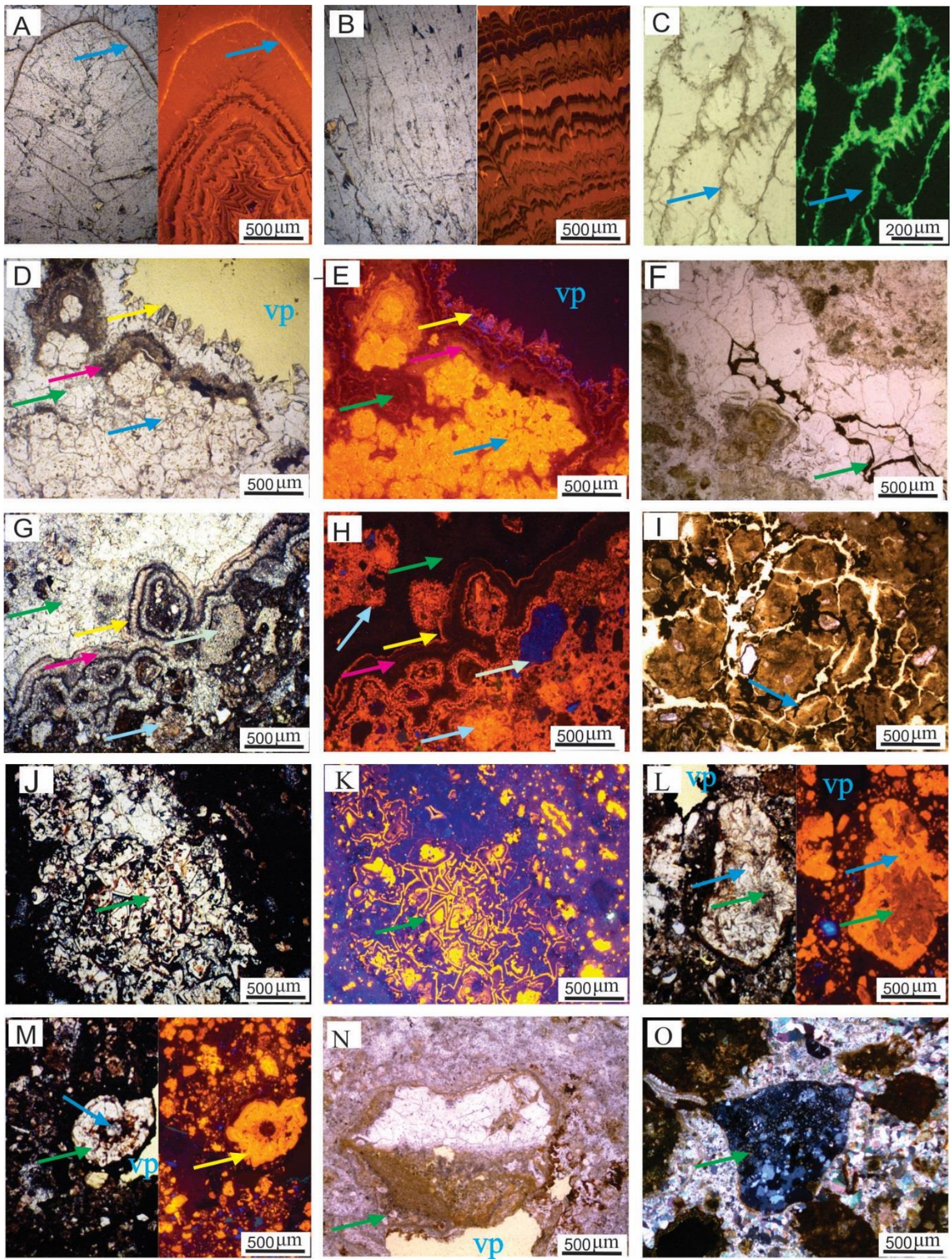

Fig. 8. Microphotographs of diagenetic features (transmitted light TL, polarizing light PL, cathodoluminescence $\mathrm{CL}$ and fluorescence light FL). A, B and C from fissure ridge, the rest from the mound travertines. (A) TL and CL of Mn-rich thin zones in banded travertine (blue arrow). (B) Zonation 
in banded travertine (TL and CL). (C) Crystal boundaries between sparitic crystalline calcite displaying bright fluorescence indicating micro-porosity along the crystal boundaries (TL and FL). (D) Thick sparry calcite crystals (blue arrow) surrounded by micritic layer (pink arrow) and scalenohedral cement (yellow arrow) together with vuggy porosity and blocky cement (green arrow) (TL). (E) CL picture of image D showing bright orange luminescence in sparry calcite (blue arrow), but dull luminescence in both blocky and scalenohedral cement and micritic layer. (F) Blocky cement draped by Fe/Mn-oxides/ hydroxides (green arrow) (TL). (G) Blocky calcite cement (green arrow) occurring between peloids together with fine grain equant cement (pink arrow) surrounding the peloids which show different generations of micrite (yellow arrow) (TL). (H) CL picture of image G representing dull luminescence in blocky and equant cements (green and pink arrow), while peloids and different generations of micrite surrounding peloids display a bright orange luminescence (blue and yellow arrow). Some volcanic grains (white arrow) display a blue luminescence. (I) Desiccation cracks (or pedogenic features: i.e. glaebules) in mudstone whereby fragments are coated by Mn/Fe oxide/hydroxide (TL). (J-K) Rhombshaped crystals with CL-zoning. A rhombohedral crystal consists of an inner large yellow luminescent crystal an outer part showing dark and thin bright yellow zonations (TL in J, CL in K). (L) Micritization displaying a dull luminescent centre and a bright luminescent outer sparitic part (TL and CL). (M) Replacement of gastropod by sparite cement with bright orange luminescence (TL and CL). (N) TL image of a cavity with geopetal micrite infilling and equant sparite cement. (O) Detrital material (green arrow) surrounded by calcite cement (PL).

\subsection{Geochemistry}

\subsection{1. ${ }^{87} \mathrm{Sr} /{ }^{86} \mathrm{Sr}$ isotopes}

Results of ${ }^{87} \mathrm{Sr} /{ }^{86} \mathrm{Sr}$ isotope analysis from representative fissure ridge and mound carbonates together with adjacent volcanic rocks are presented in Table 1 . The results for fissure ridge calcites display ${ }^{87} \mathrm{Sr} /{ }^{86} \mathrm{Sr}$ ratios varying between 0.708742 and 0.708930 , with an average of 0.708815 . The results for the mound carbonates range between 0.708742 and 0.708946 with an average of 0.708862 . The samples for volcanic rocks vary from 0.705245 to 0.721002 with an average of 0.712505 . Notably, the lowest 
values in the volcanic rock samples relate to basalt samples with somewhat higher values in granite samples.

\begin{tabular}{|c|c|c|c|c|}
\hline Location & Sample & $\mathrm{Rb}$ (ppm.) & $\begin{array}{l}\mathrm{Sr} \\
(\mathrm{ppm} .)\end{array}$ & ${ }^{87} \mathrm{Sr} /{ }^{86} \mathrm{Sr}$ \\
\hline \multirow[t]{7}{*}{ Mound } & IR(M)17ZM004 & 37 & 444 & 0.708742 \\
\hline & IR(M)17ZM009 & 9 & 637 & 0.708880 \\
\hline & IR(M)17ZM015 & 34 & 1106 & 0.708858 \\
\hline & IR(M)17ZM017 & 17 & 1111 & 0.708810 \\
\hline & IR(M)17ZM017 (cement) & 14 & 235 & 0.708895 \\
\hline & IR(M)17ZM018 & 31 & 531 & 0.708946 \\
\hline & IR(M)17ZM019 & 8 & 854 & 0.708905 \\
\hline \multirow{9}{*}{$\begin{array}{l}\text { Fissure } \\
\text { ridge }\end{array}$} & IR(F)17ZM003 & 8 & 2249 & 0.708811 \\
\hline & IR(F)17ZM004 & 10 & 2298 & 0.708930 \\
\hline & IR(F)17ZM008 & 11 & 3208 & 0,708794 \\
\hline & IR(F)17ZM009 & 17 & 1031 & 0.708794 \\
\hline & IR(F)17ZM020 & 10 & 1104 & 0.708860 \\
\hline & $\mathrm{IR}(\mathrm{F}) 17 \mathrm{ZM} 021$ & 8 & 2025 & 0.708817 \\
\hline & IR(F)18ZM046 & 23 & 2776 & 0.708781 \\
\hline & IR(F)18ZM063 & 13 & 1149 & 0.708742 \\
\hline & IR(F)18ZM064 & 10 & 1298 & 0.708804 \\
\hline \multirow{4}{*}{$\begin{array}{l}\text { Volcanic } \\
\text { rock }\end{array}$} & IR(V)18ZM065 (granite) & $\mathrm{nm}$ & $\mathrm{nm}$ & 0.721002 \\
\hline & IR(V)18ZM066 (basalt) & $\mathrm{nm}$ & $\mathrm{nm}$ & 0.707671 \\
\hline & IR(V)18ZM067 (granite) & $\mathrm{nm}$ & $\mathrm{nm}$ & 0.720688 \\
\hline & $\begin{array}{l}\text { IR(V)18ZM068 (basaltic } \\
\text { lava) }\end{array}$ & $\mathrm{nm}$ & $\mathrm{nm}$ & 0.705245 \\
\hline
\end{tabular}

Table $1 .{ }^{87} \mathrm{Sr} /{ }^{86} \mathrm{Sr}$ isotope ratio of 21 samples of fissure ridge, mound carbonates and volcanic rocks that occur adjacent to the travertine deposits together with the Rb-Sr trace element composition of these samples $(\mathrm{nm}=$ not mesured $)$.

\subsubsection{Stable C- and O-isotopes}

The $\delta^{13} \mathrm{C}$ and $\delta^{18} \mathrm{O}$ results of 21 sparite and micrite samples from the fissure ridge and 35 samples of micrite and cement from the mound geobody travertines are plotted in Fig. 9. The values of the components analysed are shown in Appendix 1. In the fissure ridge, $\delta^{13} \mathrm{C}$ values possess a mean value 
of $+8.5 \%$ and range from +7 to $+10 \%$ V-PDB. The $\delta^{18} \mathrm{O}$ values range between +0.53 and $-3.4 \% \mathrm{~V}$ PDB with a mean value of $-1.8 \%$. For the bulk mound carbonates, the mean value of $\delta^{13} \mathrm{C}$ is $+7.6 \%$, with a range from +4.0 to $+9.9 \%$. The mean $\delta^{18} \mathrm{O}$ value is $-7.8 \%$, with a range from to -9.3 to $-5.7 \%$ o V-PDB. Micrite samples of the mound structure show an overall enrichment of $\delta^{18} \mathrm{O}$ and $\delta^{13} \mathrm{C}$ in comparison to values from cement phases taken from the same samples (Fig. 9).

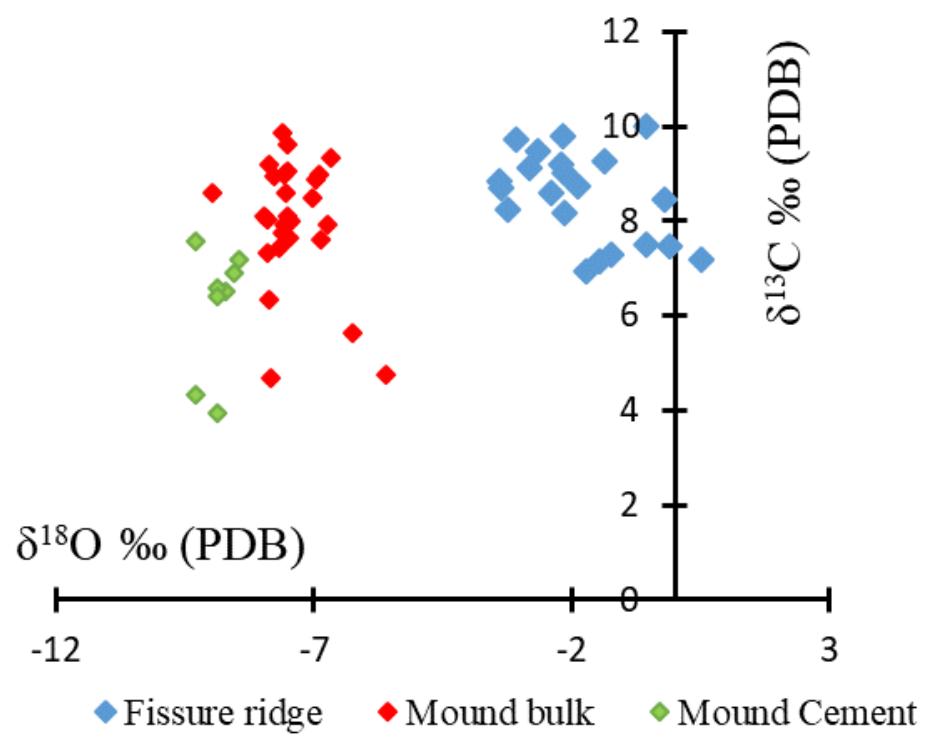

Fig. 9. A) Cross plot of stable carbon versus oxygen isotopes of fissure ridge and mound spring carbonates (bulk samples and cements).

\subsubsection{Trace element geochemistry (ICP-OES)}

The results of elemental analysis $(\mathrm{Ca}, \mathrm{Al}, \mathrm{As}, \mathrm{Cr}, \mathrm{Fe}, \mathrm{K}, \mathrm{Mg}, \mathrm{Mn}, \mathrm{Na}, \mathrm{Ni}, \mathrm{P}, \mathrm{Rb}, \mathrm{S}, \mathrm{Sr}$, and $\mathrm{Ti}$ ) of 60 samples from both fissure ridge and mound geobodies are plotted in Fig. 10. Results of $\mathrm{Zn}, \mathrm{V}, \mathrm{Co}, \mathrm{Cu}$, $\mathrm{Pb}$ and $\mathrm{Li}$ are not shown since their concentrations are low and close to the detection limit. Note that some elements mainly relate to the non-carbonate content (e.g. Al, As, $\mathrm{Cr}, \mathrm{Fe}$ ) while others are carbonate related (e.g. Sr). The elemental compositions clearly differ between geobody types, especially for elements that relate to the non-carbonate fraction. The influence of the latter is reflected by higher concentrations in the mound carbonates compared to the fissure ridge, as well as their mutual covariance ( $\mathrm{Al}, \mathrm{As}, \mathrm{K}, \mathrm{Fe}, \mathrm{Mn}, \mathrm{Rb}$, and $\mathrm{Ti}$ ). For the elements that relate more to carbonate phases, they 
possess higher concentrations in the fissure ridge. Sulphur displays about the same concentration in both geobodies, while $\mathrm{Sr}$ is much higher in the fissure ridge.
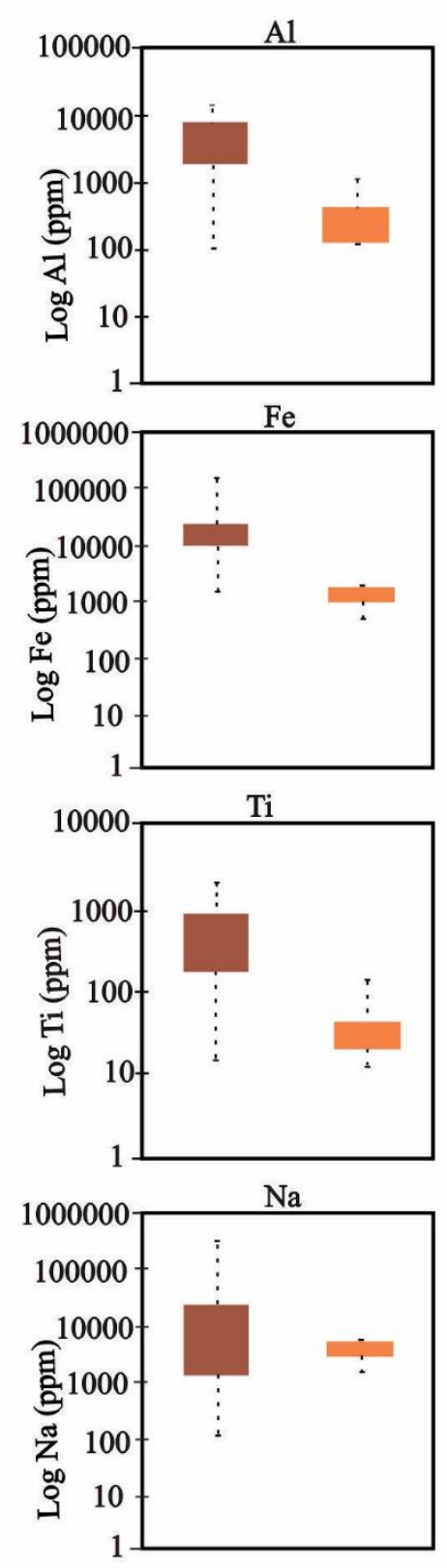

Travertine Mound
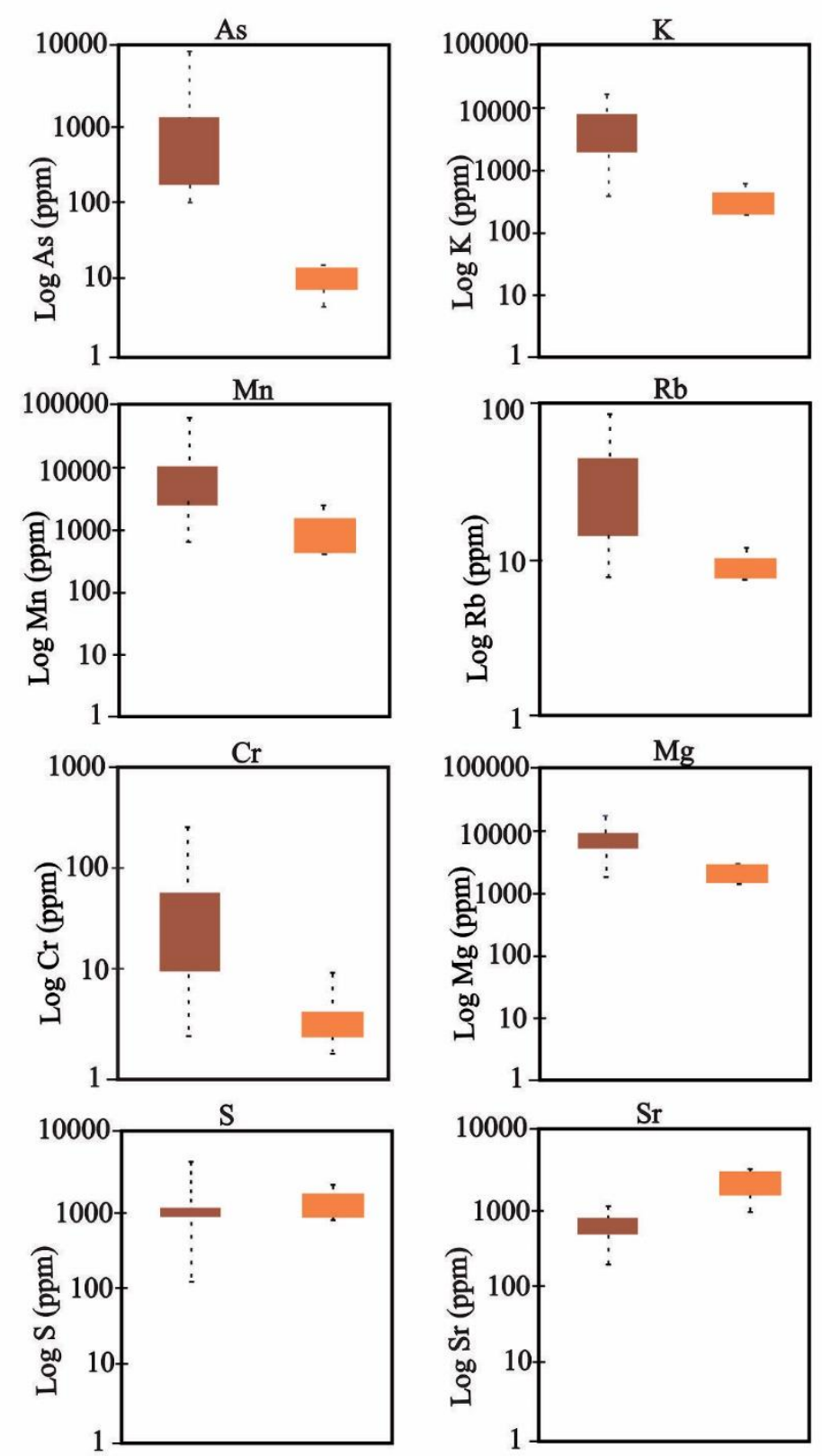

Fig. 10. Boxplots of the element concentrations in the fissure ridge and mound carbonates.

\subsubsection{Trace element geochemistry (EPMA)}

Cathodoluminescence microscopy shows that all fissure ridge carbonates and some of the mound coarse crystalline carbonates possess some bright luminescent zones. In an attempt to deduce whether the trace 
elements $\mathrm{Mn}$ and Fe, which are known to act respectively as luminescence activator and quencher (e.g., Marshall, 1988; Machel et al., 1991; Machel, 2000; Richter et al., 2003 and Boggs and Kingsley, 2006) control luminescence, qualitative EPMA analysis was carried out. These measurements in luminescent mound samples display rather uniform $\mathrm{Ca}$ and $\mathrm{Sr}$ concentrations, while high $\mathrm{Mn}$ values were encountered in bright luminescent zones. $\mathrm{Fe}$ and $\mathrm{Mn}$ concentrations in CL-zonations in banded travertine from the fissure ridge show the same distribution of high $\mathrm{Mn}$ and low Fe concentration in the bright luminescent zones and a reverse pattern in non-luminescent zones. However, the zonation in crystalline dendrites displays a different pattern. Trace and major element contents both show low concentrations in non-luminescent areas which correspond to areas with micro-porosity. The concentration of S shows a co-variance with $\mathrm{Mn}$, while $\mathrm{Mg}$ shows a reverse pattern to Mn (Fig. 11).

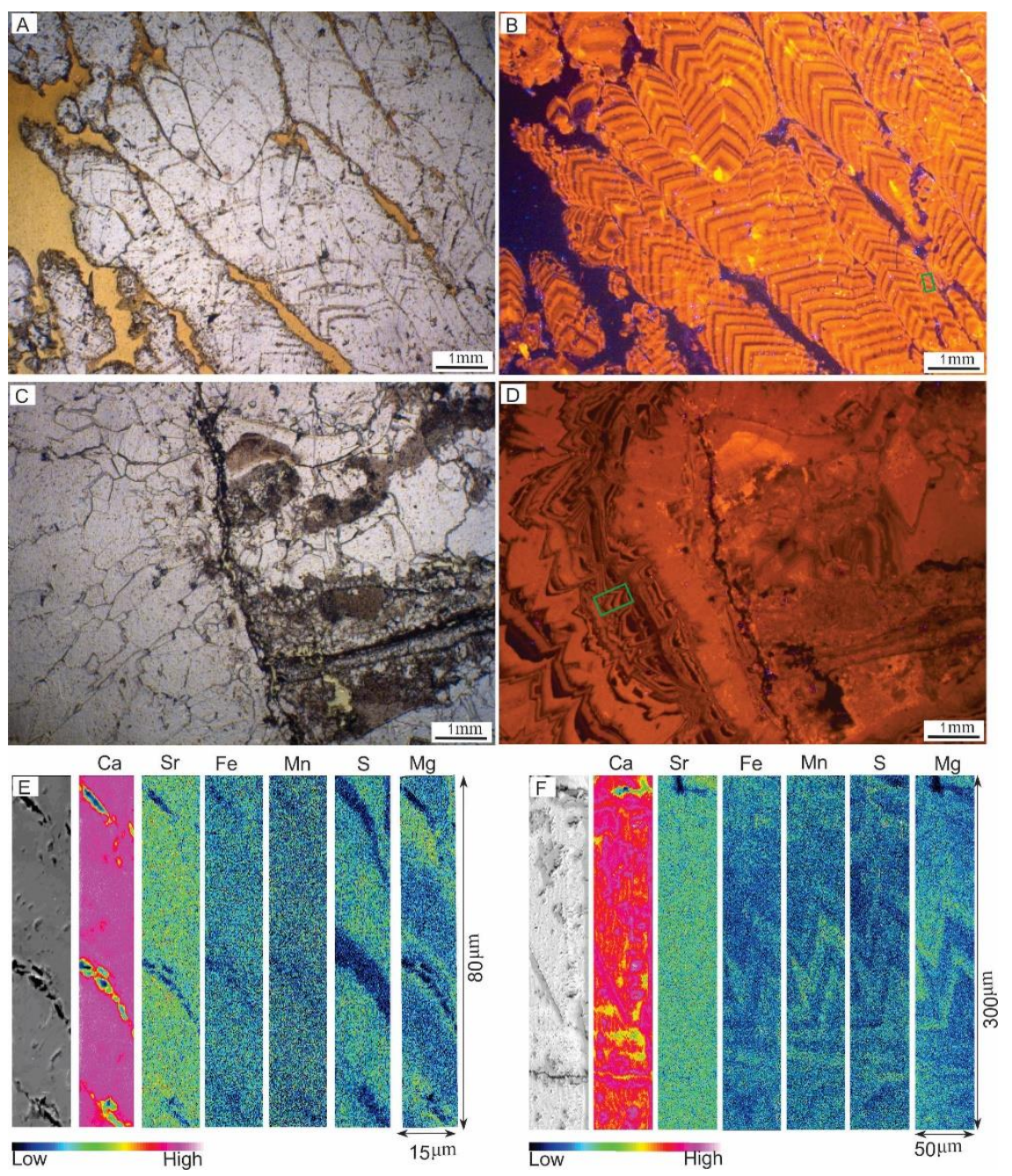


Fig. 11. A.TL) Straight and thick sparite alternating with thin micrite laminae of sharp branching feather-like dendritic crystalline dendrites from fissure ridge. B.CL) Bright luminescence with zonation of (A). C.TL) Boundary between banded travertine lamina and micritic laminite bindstones from fissure ridge. (D.CL) Bright luminescence with zonation of (C). (E and F) Relative elemental distribution of zoned carbonate crystal, revealing variations in element oxide composition. Locations of sample $\mathrm{E}$ and F are indicated with green rectangular lines in Fig. 11B and D respectively. The picture to the left in E and $\mathrm{F}$ is back scatter.

\subsubsection{Water chemistry}

Water quality measurements and chemistry analyses collected from a fresh water well (A) and a spring (B) at $1 \mathrm{~km}$ distance of the travertine deposits and two travertine springs adjacent to the studied geobodies can be found in table 1 . Travertine spring 1 occurs next to the fissure ridge at $20 \mathrm{~m}$ distance and travertine spring 2 occurs next to the mound at a distance of $100 \mathrm{~m}$. The in-situ measurements show current temperatures of $14^{\circ} \mathrm{C}$ for water springs $\mathrm{A}$ and $\mathrm{B}, 15^{\circ} \mathrm{C}$ for travertine spring 1 and $20^{\circ} \mathrm{C}$ for travertine spring 2. Water collected form travertine spring 1 has a $\delta^{18} \mathrm{O}(\mathrm{SMOW})$ value of $-9.5 \%$ and a $\delta^{13} \mathrm{C}_{\text {DIC }}$ (V-PDB) value of 3.7\% . n spring 2 a $\delta^{18} \mathrm{O}$ (SMOW) value of $-3.1 \%$ and a $\delta^{13} \mathrm{C}_{\text {DIC }}$ (V-PDB) value of $-0.6 \%$ was measured. Travertine spring 1 is also rich in alkalinity with $63.4 \mathrm{mmol} / \mathrm{kg}$, while travertine spring 2 has an alkalinity value of $23.2 \mathrm{mmol} / \mathrm{kg}$. The latter clearly differs from the low alkaline water wells A and B. Of major importance however is that the two travertine springs show distinct differences in both stable isotope signatures and alkalinity as expected based on the differences in sedimentology and geochemistry of fissure ridge and mound deposits.

\section{Discussion}

\subsection{Depositional environment}

Outcrop observations and macroscopic description of the carbonates allow to interpret the different lithotypes and their setting. They are discussed here from top to flank of each geobody. At the top of the fissure ridge, a low-angle slope occurs around the fissure. At a lateral distance of $\sim 6 \mathrm{~m}$, first a steep slope carbonate facies developed which evolves into smooth slope facies carbonates. At the top of the 
mound, the central pond ( $\sim 15 \mathrm{~m}$ in diameter) is immediately followed laterally by a smooth slope with a dip up to $20^{\circ}$. In contrast to the fissure ridge, the mound does not show a systematic order of lithotypes, thus reflecting strong lateral and vertical changes (see Fig. 3 and 5).

In the centre of the fissure ridge geobody, along the fissure, a banded travertine occurs. The sparitic crystalline appearance with clear discrete micritic laminae obviously precipitated from the upwelling of thermal waters flowing out at the ridge top. These waters likely were highly supersaturated with respect to calcite leading to pure sparitic calcite precipitation. The existence of micron to millimetre sized micrite laminae in the sparite crystals is corroborating with a variation in upwelling water discharge. Surrounding the banded travertine, micritic laminae with gas bubbles occur. These are the first deposits that formed near the vent. Formation in this setting of micrite instead of sparite can be explained by the narrow pan shaped depressional shape of the precipitation environment, with a lack of major turbulence compared to the adjacent slope setting. The formation of micritic laminae here agrees with the microbial lithotype as reported by Gandin and Capezzuoli (2008). According to the latter authors, the conditions in such setting are favourable for microbial activity, however, no clear signs of microbes were found in the studied micrites. The elongated pan shape depression turns into a steep slope that finally smoothens along both sides of the ridge. It is made up by crusts that consist of crystalline dendrites. In analogy with reported active cases, the latter formed within highly supersaturated fast flowing waters with intense $\mathrm{CO}_{2}$ degassing (Gonzalez et al., 1992; Jones and Renaut, 1995; Chafetz and Guidry, 1999; Gandin and Capezzuoli, 2008). The crystalline dendrite lithotype displays parallel and non-undulating laminae in the ridge flank and thick dendritic shaped crusts along the steep slope and within micro-terraces. These thick crusts change into thin dendritic shaped crystals and granular sparite at the downside of the steep slope. The absence of microbial fabrics/traces together with straight and crystalline branching features point to an abiotic origin of these fabric. This observation is in line with the studies of Guo and Riding (1998), Chafetz and Guidry (1999) and Jones and Renaut (2010) who also reported a non-microbial origin of similar sparitic laminar lithotypes. The systematic change observed along the flow path suggests that the fabric is significantly influenced by substrate topography. As the hydrodynamic conditions changed along the steep to smooth slope, the 
physico-chemical (e.g. calcite saturation), $\mathrm{CO}_{2}$ degassing and water flow saturation decreased. Microbial activity may be facilitated inducing a decrease in sparite laminae thickness and causing an increase in the formation of thin, dark and microporous micritic laminae. Similar laminations with thick sparitic and thin microporous micrite laminae have been reported as laminae-discontinuities by Rodriguez-Berriguete et al. (2018) and likely reflect variation in fluid irrigation cycles.

At the top of the mound, a stromatolite boundstone occurs displaying conical laminae similar to domed and columnar microbialite bioherms reported by Arenas and Pomar (2010). The co-existence of some coated bubbles, elsewhere attributed to organic decay (Chafetz et al., 1991a,b), is in line with the microbially mediated origin of this lithotype. Algal mudstone is another lithotype that is mainly present within the spring pond. This lithotype is marked by the presence of algae floating in carbonate mud. The absence of desiccation features supports a subaqueous environment. The lack of sparitic fabrics or grain components, which normally evidence fast precipitation, implies low fluid flow dynamics to even standing water. Microbial mediation in algal mudstone points towards a biological friendly environment during precipitation which is also supported by the gastropods and ostracods encountered. Conversely, the sparitic grainstone lithotype implies highly supersaturated water fluxes in the spring pond, also marked by limited microbial influence. This means that the water hydrodynamic conditions and possibly its composition changed during precipitation which can be attributed to tectonic activity in the study area. On the barrage, pisoid wackestones/packstones dominantly occur. The pisoids are marked by an alternation of sparite and micrite laminae pointing to a cyclic variation in physico-chemical environmental conditions during their formation. Sparitic laminae indicate higher saturation or faster fluid flow while micritic cortexes can be regarded as products of lower saturation or interference of microbial activity. However, distinct microbial textures have not been observed. The presence of meniscus cements suggests temporary vadose-like conditions, which is in line with a setting close to the edge of the pond. Phyto-rudstones/boundstones usually develop from the pond edge to the trail part of the mound, where physico-chemical conditions in the water equilibrate with the ambient environment. Through time, the thermal water induces active carbonate precipitation around plant leafs. During fluid flow in the smooth slope setting, peloid extraclast packstones contain rounded to sub- 
rounded grains floating in a micrite to microsparitic matrix suggesting high flow energy. The latter is caused by water flowing downslope and consequently the occurrence of turbulence in which clump aggregates formed. Decay of organic matter is a possible reason for the creation of fine fenestral-like pores in the peloid extraclast packstone lithotype. This pore type makes this lithotype vulnerable to diagenetic alteration, as testified by bright luminescing calcite cements. Also the outer part of the allochems are bright luminescent, indicating that they have been recrystallized by interaction with the cementing waters.

At the foot of the mound, where a smooth slope setting occurs, water flow slowed down and massive $\mathrm{Mn} / \mathrm{Fe}$-oxide/hydroxides stained lime mudstone formed. The presence of fragments and fractures can result from desiccation, pointing to very shallow water conditions with temporary emergence. The $\mathrm{Mn} / \mathrm{Fe}$-oxide/hydroxides are likely either derived from the alteration and erosion of substrate lithologies and/or adjacent volcanic rocks or from leaching of volcanic fragments in the mound carbonates during exposure. Their presence in the lime mudstone reflects oxidative conditions. However, whether this means that the mudstones formed under oxidative conditions, or whether the lime mudstone was subsequently oxidized at near surface conditions cannot be inferred. At the tail of the smooth slope, the silty mudstone lithotype containing widespread extraclasts occur. Its depositional environment can be interpreted to correspond to a shallow pond which formed at the edge of a smooth slope reflecting alluvial plain conditions. Such an alluvial plain is occasionally influenced by subaerial exposure and pedogenesis as reported by Miall (1996) and Croci et al. (2016) from comparable settings elsewhere. Furthermore, this lithotype is always associated with lime mudstone which also supports a low energy water setting. Within such setting it is not likely that erosion of volcanic rocks could have taken place. Consequently, the extraclasts in this lithotype likely were imported during heavy rains. This means that during the development of this lithotype, precipitation and sedimentation occurred in a setting with mixed thermal and meteoric water.

\subsection{Diagenesis and pore types}

Despite the lack of burial diagenesis, the studied strata have been subjected to early diagenetic processes. However, diagenesis differs between both geobodies studied. In the mound structure, 
diagenetic overprinting such as the formation of gravitationally induced fractures, cementation, and recrystallization is omnipresent. Furthermore, the formation of $\mathrm{Mn} / \mathrm{Fe}$-oxide/hydroxides can be attributed to a reaction between and within the fluid forming the travertine mound deposit and its surrounding/bedrock lithologies or can be due to meteoric alteration. In some primary micrite phases bright luminescent spots occur at locations affected by recrystallization (see Fig. 8L). The presence of different kind of cement phases can be interpreted as diagenetic fabrics which precipitated from springwater that circulated through the open pore space of partially lithified or unconsolidated travertine. Based on the origin of this spring water that likely mixed with meteoric water, bright and dull luminescent phases respectively formed (e.g. Fig. 8D to H). This interpretation is based on the fact that all primary sparite phases show a bright luminescence whereby their formation likely reflects springwater dominance. Dissolution mainly affected ostracods and gastropods (see Fig. 8N and M), likely reflecting their original aragonite mineralogy. Afterwards, these moulds were filled by cement. Locally some matrix partially dissolved producing vuggy pores which are likely related to the infiltration of calcite undersaturated meteoric water.

The main diagenetic process in the fissure ridge is micritization resulting in widespread micropores in the border of sparite crystals within the crystalline dendrite lithotype (see Fig. 6G and H). Widespread microporosity is proven by the bright fluorescent colour of impregnated samples. In addition, the low total concentration of both major and trace elements measured by EPMA supports the interference of microporosity during the areal spot analysis (Fig. 11C and D). This microporosity development could be due to surface weathering. The dark and light-coloured laminae forming zonations in banded travertine, however, do not show any microporosity in dark coloured phases under the microscope. The regular and systematic repetition of dull and bright luminescence suggests that these patterns are controlled by a regular natural phenomenon possibly related to seasonal variations or cyclicity in spring activity. Cementation, which is especially affecting micritic laminites consisting of gas bubble bindstone lithotype, is possibly related to fluid infiltration into the porous micritic laminites.

The widespread diagenetic features characterising the mound setting, like gravitationally induced open fractures, the variety of cement types and especially Fe/Mn-oxide/hydroxide formation, have not been 
observed in the fissure ridge setting. In contrast, the well-organized fine zonation in fissure ridge sparites does not appear in mound phases. Such a distinct difference in diagenetic features between the two geobodies supports the interpretation that diagenetic alteration is related to the primary fabric which in its turn is related to the initial water chemistry and the geological setting. Accordingly, in the fissure ridge, fast precipitation due to high alkalinity fluid and high calcite saturation gave rise to a non-porous, consolidated and compact lithology that is less susceptible for early diagenetic processes and/or gravitational fracturing, while the lower fluid saturation and related alkalinity in the mound geobody water resulted in a lithology that is less consolidated and more susceptible to early diagenetic processes.

\subsection{Geochemistry}

\section{${ }^{87} \mathrm{Sr} /{ }^{86} \mathrm{Sr}$ isotope}

In travertine, the Sr isotopic signature reflects the characteristics of the precipitating fluids which may be linked to the signature of the dissolved parent carbonates (Minissale et al., 2002; El Desouky et al., 2015; Berardi et al., 2016). Therefore, the Sr isotope results often can be used as a fingerprint of the dissolved parent marine carbonate sources with reference to the Sr seawater curve of McArthur and Howarth (2004) (Fig. 12) or, ideally, measured data from potential source rocks. The average ${ }^{87} \mathrm{Sr} /{ }^{86} \mathrm{Sr}$ ratio of $\sim 0.7085$ found in the two carbonate geobodies, which corresponds to one of the few important similarities between both geobodies, is identical to the ${ }^{87} \mathrm{Sr} /{ }^{86} \mathrm{Sr}$ ratios of Cenozoic carbonate formations in Central Iran and the Sanandaj-Sirjan Zone. These carbonates belong to the Qom Formation comprising thick successions of marine limestones, marls, evaporite and siliciclastics (Reuter et al., 2009). This formation likely acted as the main subsurface water aquifer. The reservoir characteristics of the Qom Formation are also reflected by the fact that this formation is one of the main carbonate petroleum reservoirs in Iran (Reuter et al., 2009). It should be noted that marine Cambrium carbonates that yield a similar Sr-isotopic signature (Fig. 12) can be excluded given their absence in the study area. Moreover, most ${ }^{87} \mathrm{Sr} /{ }^{86} \mathrm{Sr}$ ratios of (not in situ) volcanic rocks found around the studied gebodies deviate from the signature of the travertines, suggesting that fluid-rock interaction with nearby volcanic rocks

during subsurface fluid circulation was minimal. However, the ${ }^{87} \mathrm{Sr} /{ }^{86} \mathrm{Sr}$ ratio reported by Azizi et al. (2013) from Quaternary volcanics in the north Ghorveh area (situated about $10 \mathrm{~km}$ from the study area) 
shows a mean value of 0.705445 which is close to that of the studied travertines. Therefore, water/rock interaction under near-surface conditions cannot be excluded. Such interaction could explain the input of $\mathrm{Mn}$ and $\mathrm{Fe}$ for example and the incorporation of altered volcanic constituents in the mound travertines. Given that the variation of the ${ }^{87} \mathrm{Sr} /{ }^{86} \mathrm{Sr}$ ratio of the volcanic rocks is higher and their average signature is lower compared to that of the travertines, it is considered unlikely that they acted as a main source rock.

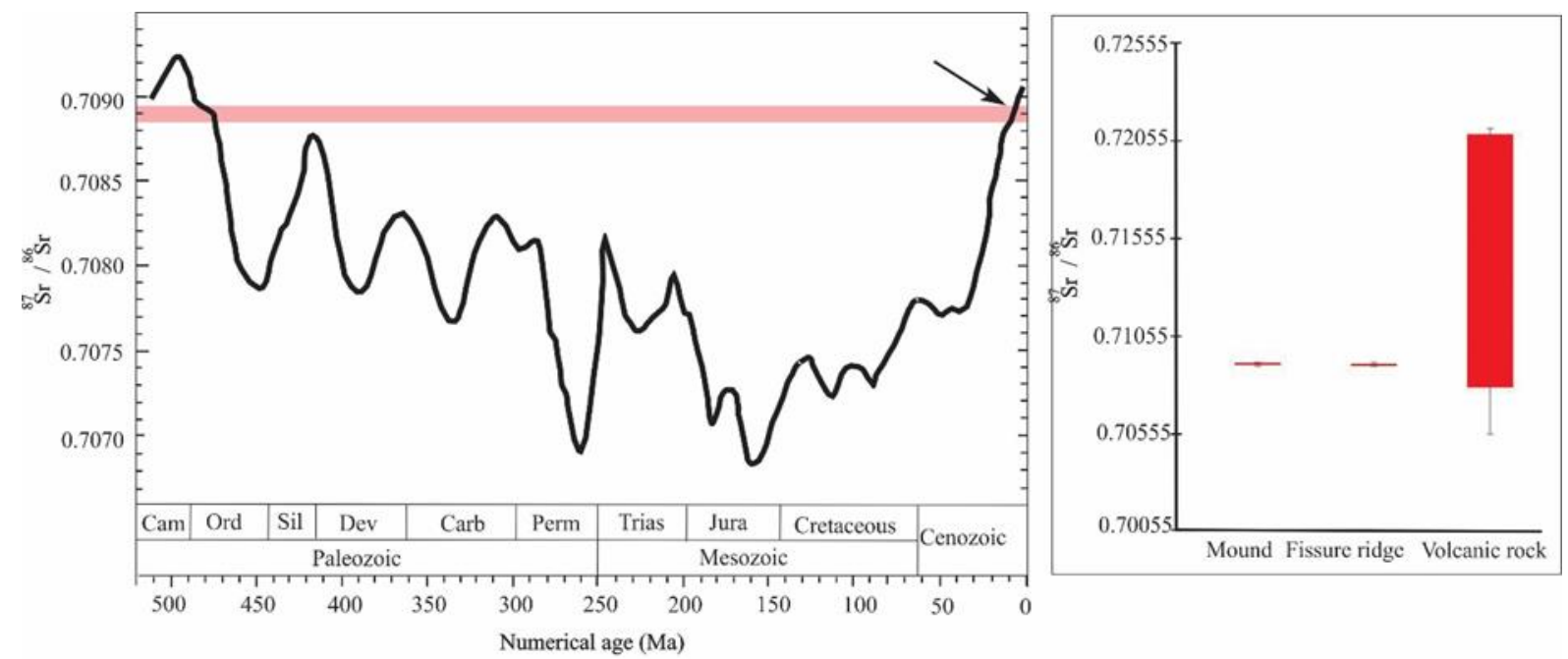

Fig. 12. Range of ${ }^{87} \mathrm{Sr} /{ }^{86} \mathrm{Sr}$ ratios for both mound and fissure ridge carbonate samples plotted along the marine Sr-isotope seawater curve modified from McArthur and Howarth (2004). The arrow indicates the parent carbonate source rocks recognized from the lithostratigraphic section as the Qom Formation. On the right side, a boxplot of the ${ }^{87} \mathrm{Sr} /{ }^{86} \mathrm{Sr}$ isotope ratio of fissure ridge, mound carbonates and adjacent volcanic rocks is given.

\section{Stable C- and O-isotopes}

Travertine stable $\mathrm{C}$ - and $\mathrm{O}$-isotopes are strongly controlled by the type of water involved and the precipitation temperature, as well as the source rock with which the water interacted and the origin of $\mathrm{CO}_{2}$ (Guo et al., 1996; Pentecost, 2005; Kele et al., 2011; Della Porta et al., 2017). The $\delta^{13} \mathrm{C}$ values are rather similar for both studied geobodies, while their $\delta^{18} \mathrm{O}$ values are clearly different. In general, the $\delta^{13} \mathrm{C}$ signature mainly relates to sources of dissolved $\mathrm{CO}_{2}$ and $\mathrm{HCO}_{3}{ }^{-}$of travertine precipitating waters. 
It can also partially be influenced by water-rock interactions during fluid resurfacing and evaporation of $\mathrm{CO}_{2}$ as well as degassing/outgassing of $\mathrm{CO}_{2}$ (Kele et al., 2008, 2011).

Applying the empirical equation of Panichi and Tongiorgi (1976), which allows estimating the $\delta^{13} \mathrm{C}$ of the $\mathrm{CO}_{2}$ from the precipitating waters for both mound and fissure ridge carbonates samples near their vents results in values ranging between -2.8 to $+0.3 \%$. According to Hoefs (2004), Kele et al. (2011) and Claes et al. (2015) such $\delta^{13} \mathrm{C}$ signature points to thermal decarbonation from a marine carbonate origin of the $\mathrm{CO}_{2}$. The $\delta^{13} \mathrm{C}$ values of the carbonates of the Qom Formation, between -0.84 and $+1.47 \%$ (Ballato et al., 2011) are in line with these estimates. The measured data for Spring 2 (Table 2) is in the same range, while that of Spring 1 is higher.

The positive $\delta^{13} \mathrm{C}$-signatures in both geobodies are in line with a thermogenic origin as described by Pentecost (2005). In the mound carbonates, however, more samples occur that are less positive, supporting the interpretation of a possible minor contribution by soil related $\mathrm{CO}_{2}$ in the meteoric water component. The latter is for example reflected by the lower $\delta^{13} \mathrm{C}$-value in phyto-boundstone/rudstone lithotype which precipitated from less saturated and cooler waters.

The $\delta^{18} \mathrm{O}$ signatures are distinct for both geobodies (i.e. -3.4 to $+0.53 \%$ V-PDB for fissure ridge and 9.3 to $-5.7 \%$ V-PDB for mound). This difference is either primary and related to the fluid involved in the precipitation of these deposits or it is a consequence of diagenetic alteration which has reset the original mound carbonate signatures. The latter is examined by analysing both the micrite matrix and diagenetic cement phases in the mound geobody (Fig. 10). In the latter figure, it can be seen that the cement phases are more depleted for both carbon and oxygen isotopes (up to $2 \%$ ). If the cements are related to meteoric diagenesis, we have to assume that the $\delta^{13} \mathrm{C}$ signature became carbonate buffered, which is in line with the observed diagenetic overprinting. With regard to the slightly lower $\delta^{13} \mathrm{C}$ signatures an explanation has already been given above. The $\delta^{18} \mathrm{O}$ difference between the mound micrite matrix and cement samples is small. The average 6\% (V-PDB) difference in the oxygen isotopic composition between mound and fissure ridge cannot easily be related to the diagenetic resetting. Furthermore, the $\delta^{18} \mathrm{O}$ signatures are distinct for the nearby springs (i.e. $-9.5 \%$ SMOW for Travertine Spring 2 and $-3.1 \%$ SMOW for Travertine Spring 1) and suggest primary differences in fluid 
composition. This difference in the ambient fluids can be explained by mixing of a deep subsurface sourced fluid with a vast amount of meteoric water giving rise to the mound precipitates. The fissure ridge precipitates likely reflect deposition from subsurface, rock-buffered fluids. This interpretation agrees with the high alkalinity, $\delta^{13} \mathrm{C}$ and $\delta^{18} \mathrm{O}$ signature of the travertine spring 1 nearby the fissure ridge. Under the assumption that the spring waters near the two geobodies are somehow representative of the original waters giving rise to the fissure ridge (however for spring 1 its present-day activity is likely less vigorous as for the original fissure ridge spring). Therefore, the $\delta^{18} \mathrm{O}$ signature from both water and sediment can be used in the formula proposed by Kele et al. (2011) to infer the estimated precipitation temperature. The calculated precipitation temperature of the fissure ridge varied between $25^{\circ} \mathrm{C}$ to $50^{\circ} \mathrm{C}$, while the temperature of mound water varied between $4{ }^{\circ} \mathrm{C}$ and $21^{\circ} \mathrm{C}$. Consequently, fluid flow paths and/or mixing with meteoric water were different. The former may be related to fluid circulation along faults. Even if no detailed structural geological data is available for the study area, it is clear that the development of the fissure ridge is controlled by a fault and its associated damage zone (Brogi and Capezzuoli, 2009). Moreover, faults aligned along the same direction as the fissure ridge have been reported on the geological map of the Iranian Geological Survey and by Rahmani (2012). Therefore, the mixing of a deep subsurface-sourced fluid with a vast amount of meteoric water for the mound carbonates is the most likely scenario.

\begin{tabular}{|l|l|l|l|l|l|}
\hline Spring & $\mathrm{T}\left({ }^{\circ} \mathrm{C}\right)$ & $\mathrm{pH}$ & $\begin{array}{l}\text { Total } \\
\text { Alkalinity } \\
(\mathrm{mmol} / \mathrm{kg})\end{array}$ & $\begin{array}{l}\delta^{13} \mathrm{C}_{\text {DIC }} \\
(\% \text { V-PDB })\end{array}$ & $\begin{array}{l}\delta^{18} \mathrm{O} \\
(\% \text { V-SMOW })\end{array}$ \\
\hline Travertine Spring 1 & 15 & 7.3 & 63.4 & 3.7 & -3.1 \\
\hline Travertine Spring 2 & 20 & 7.1 & 23.2 & -0.6 & -9.5 \\
\hline $\begin{array}{l}\text { Fresh water well } \\
\text { (Ghaslan) }\end{array}$ & 14 & 6.9 & 5 & -7.0 & -7.9 \\
\hline $\begin{array}{l}\text { Fresh water spring } \\
\text { (Delbaran) }\end{array}$ & 14 & 6.9 & 3.1 & -12.8 & -8.0 \\
\hline
\end{tabular}

Table 2. Temperature, $\mathrm{pH}$, alkalinity and stable isotope signatures for water samples from two travertine springs and from a fresh water well (Gaslan) and spring (Delbaran). 


\section{Trace element geochemistry}

Another major difference between the two geobodies relates to their trace element content. The relatively high concentrations of several analysed elements (e.g. Al, As, K, Fe, Mn, Rb, P, Ti, Cr, Ni and $\mathrm{Mg}$ ) in the mound carbonates is mainly related to the high percentage of petrographically identified non-carbonate phases, especially mafic volcanic components and clay minerals derived from the tuff, lapilli, pumiceous strata, marl, conglomerate and lahar and/or similar lithologies occurring in the surrounding area.

Calcareous waters precipitating the mound travertine interacted with surrounding usually mafic rocks along their flow path. The latter rocks are vulnerable to weathering. Mixing of subsurface waters with meteoric water that interacted with eroded rock material can also be invoked. In contrast, the lower values of trace elements, with the exception of $\mathrm{Sr}, \mathrm{S}$ and $\mathrm{Na}$ in the fissure ridge carbonates, can be explained by fast precipitation from highly saturated subsurface waters whereby the contribution of surface derived waters that interacted with non-carbonate lithologies was minimal. The higher $\mathrm{Sr}$ and Ca-content relates to more pure calcite phases in the fissure ridge. Both carbonate systems possess relatively high $\mathrm{S}$ and $\mathrm{Na}$ content likely reflects the saline nature of the parent fluid that interacted with evaporate-bearing source rocks. As proposed above, the lower Sr content in the mound carbonates could be pristine, due to a higher degree of mixing with meteoric water or due to diagenetic resetting. Fe and Mn likely reflect a different story. Their presence in $\mathrm{Mn} / \mathrm{Fe}$-oxide/hydroxides visibly present in the carbonates relates to the reaction with non-carbonate constituents present around or within the travertine mound, especially volcanic constituents. The presence of Fe and $\mathrm{Mn}$ can also be related to their presence in the main fluids that formed the two geobodies. In contrast with the travertines reported from several locations around the world (e.g. Kallis et al., 2000; Mallick and Frank, 2002; Sant'Anna et al., 2004; Sierralta et al., 2010; Claes et al., 2015), the studied carbonates generally show an intense luminescence, which makes them rather unique. According to Amieux et al. (1989), suboxic conditions facilitate Mn incorporation in growing calcite crystals since $\mathrm{Mn}$ is a main luminescence activator in carbonates, while oxidative conditions prohibit the incorporation of $\mathrm{Mn}$ in growing calcite crystals (Machel, 2000; Boggs and Kingsley, 2006). The reason why not all mound lithotypes show a bright luminescence is that the 
fluids that gave rise to the mound carbonates is interpreted to be related to the mixing with infiltrating meteoric water which is usually oxygen-rich as reflected in the precipitation of $\mathrm{Mn} / \mathrm{Fe}$-oxide/hydroxides in the mound. This mixing also decreased the saturation degree which was not sufficiently high to induce fast precipitation, as reflected by the impure micritic fabrics. Some bright luminescent phases, however, developed during diagenesis in relation to recrystallization of micrite under suboxic conditions, which could have occurred due to oxygen consumption during organic decay (e.g. from reeds, grasses, algae, etc.).

Crystalline dendrite and banded travertine lithotypes in the fissure ridge display intriguing CL zonations. In crystalline dendrite, dull luminescence zones mainly correspond to thin microporous laminae, which can be related to a lower precipitation rate. This lower precipitation rate is likely caused by lower water saturation. The EPMA mapping shows that these microporous and non-luminescent parts contain the lowest total element concentrations (see Fig. 11). A well-developed micro-porosity can be inferred from fluorescence microscopy (see Fig. 6G and H). The explanation for the banded travertine lithotype, is however different due to the absence of micrite and microporosity in these precipitates. The occurrence of systematic dull and bright luminescent zones supports a variation in saturation degree possibly caused by seasonal variations. The lack of micro-porosity in banded travertine in comparison with crystalline dendrite can be due to the subaqueous precipitation environment that was less susceptible to near-surface weathering.

\subsection{Main factors controlling variation in sedimentology, diagenesis and geochemistry of two neighbouring geobodies}

The main factors controlling the different geobody morphologies and characteristic sedimentology, diagenetic and geochemistry features can be related to the influence of the bedrock on the hydrology. Based on the map provided by the Geological Survey of Iran of the study area (see Fig. 1C), a fault separates the non-porous argillaceous limestone near the fissure ridge side from volcanic tuff and lapilli/pumiceous tuff along the mound side. Since no detailed geophysical nor structural data are available no exact information on the fault position exists, which is important since both travertine geobodies occur adjacent to each other. Brogi and Capezzuoli (2009) showed that asymmetrical fissure 
ridges develop along normal faults with vertical displacement, while symmetrical fissure ridges relate to fractures and/or transtensional faults without major vertical displacement. Accordingly, the Babagorgor fissure ridge with its symmetrical outline and same ridge height and structure at opposite sides of the fissure with equal travertine thicknesses, content, and distribution likely reflect development along a strike slip fault. Moreover, according to Hancock et al. (1999) travertine fissure-ridges mainly develop on hard and brittle bedrock, while isolated thermal springs, such as towers, pinnacles, mounds and tufa cones generally form upon unconsolidated, soft and ductile sediments (Brogi and Capezzuoli, 2009). Therefore, it is very likely that the fissure ridge formed upon a satellite fault of the major strike slip fault present in the limestone bedrock, while the mound developed upon a tuff and lapilli/pumiceous tuff bedrock present along the other side of strike slip fault. This interpretation is in line with the vast presence of volcanic fragments in the mound travertines. These volcanic fragments do not occur in fissure ridge travertines. The thermal water which was sourced from the same deep reservoir for both travertine deposits as inferred from the uniform ${ }^{87} \mathrm{Sr} /{ }^{86} \mathrm{Sr}$ analyses, travelled along different pathways at some point in the subsurface (Fig. 13). As Curewitz and Carson (1997) reported, thermal water upwelling is strictly related to permeability. Accordingly, tuff and lapilli/pumiceous tuff can be considered as highly porous rock, which is even enhanced when they are fractured adjacent to a major fault. Such high porosity and permeability provided suitable conditions for the mixing of thermal water with groundwater. This can explain the $6 \%$ depletion in the $\delta^{18} \mathrm{O}$ value recorded in the mound carbonates and the dominance of impure micritic fabrics. In contrast, due to the low porosity of subsurface limestones, the fissure ridge related fluid experienced limited mixing, thus fissure ridge precipitates likely reflect precipitation from dominantly subsurface-sourced fluids.

Despite the very close proximity between both geobodies, which are situated less than $800 \mathrm{~m}$ from each other, and notwithstanding that the thermal fluids likely originated from interaction with the same source rock, a different morphology and fabrics developed as a function of water chemistry in relation to different water-rock interactions at near-surface conditions and the mixing with meteoric water. This indicates that the bedrock directly influences water hydrochemistry, which plays an important role in fabric development and the degree of diagenetic overprinting in travertines. 


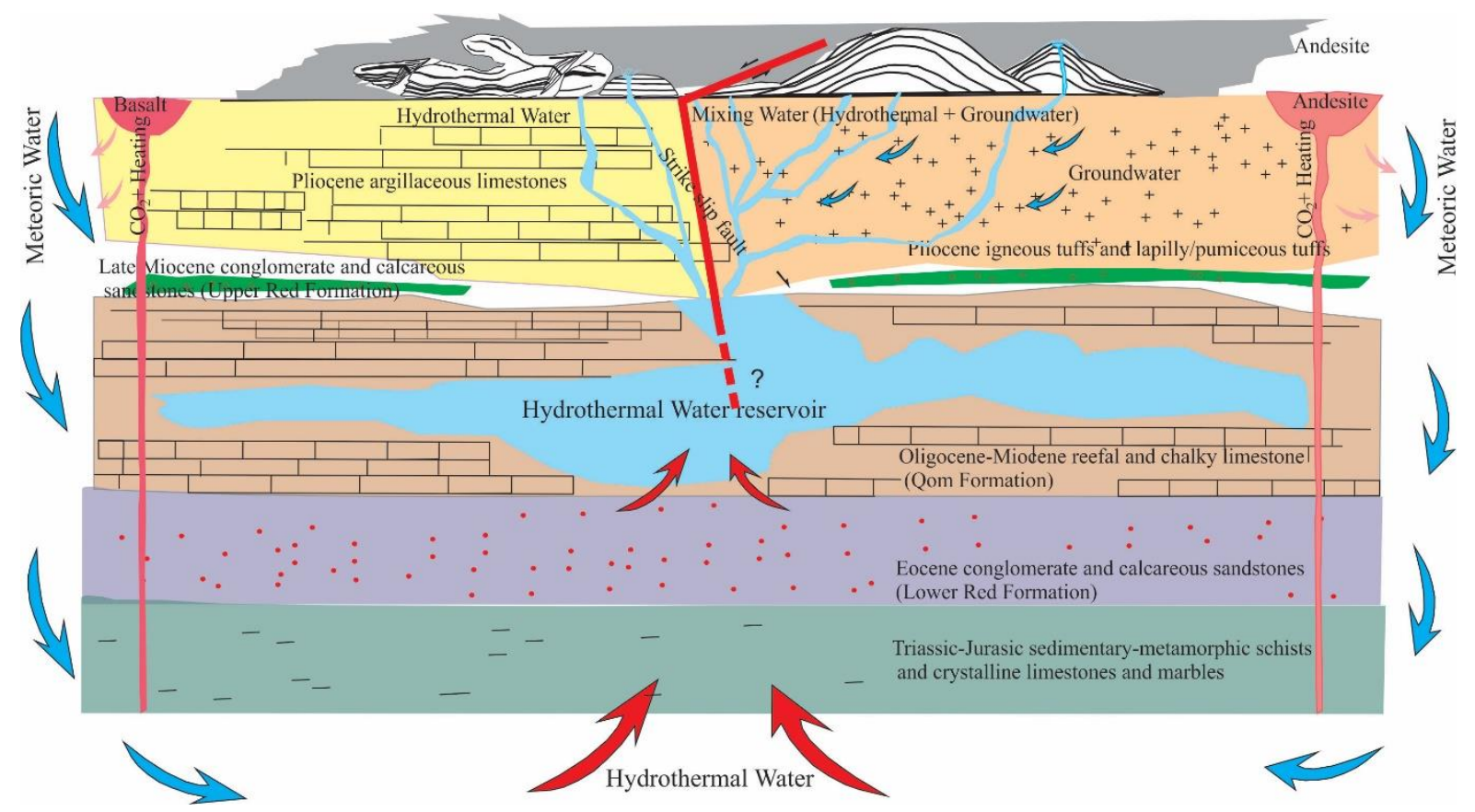

Fig. 13. Conceptual model (not to scale). Meteoric water circulation is topography-driven with infiltrations in the nearby mountain area. Upwelling of thermal water occurs along a possible strike slip fault after having migrated through the main reservoir which corresponds to the Qom Formation based on the ${ }^{87} \mathrm{Sr} /{ }^{86} \mathrm{Sr}$ ratio. Based on bedrock characteristics near the location where the fluid resurfaces, a mound or fissure ridge formed. The latter deposited on tight but fractured limestone bedrock which could thus precipitate from the dominant original thermal water. However, the mound formed on porous volcanic bedrock. Here the thermal fluid mixed with meteoric groundwater, whereby also some of the substrate constituents became mixed with the precipitating carbonates.

\section{Conclusion}

Detailed morphological, sedimentological, diagenetic and geochemical analysis of a fissure ridge and a mound carbonate geobody which occur at a distance of $\sim 800 \mathrm{~m}$ from each other, reveal major differences between both geobodies. The main differences are related to their shape and especially their rock fabric, which is sparite-dominated in the fissure ridge and micrite-dominated in the mound. The complex assemblage of lithotypes in the mound contrasts with the rather uniform nature in the fissure ridge. However, they have the same dissolved carbonate parent source rock as inferred from their similar ${ }^{87} \mathrm{Sr} /{ }^{86} \mathrm{Sr}$ ratio (ranging from 0.70874 to 0.70893 for fissure ridge and 0.70874 to 0.70895 for mound 
calcites), pointing to Cenozoic carbonate source formations in Sanandaj-Sirjan zone - Central Iran). Furthermore, $\delta^{13} \mathrm{C}$ signatures of both geobodies (ranging from +7 to $+10 \% \mathrm{~V}$ - PDB for fissure ridge and from +4 to $+9.9 \%$ V-PDB for mound calcites), points to a thermogenic fluid origin. However, the $\delta^{18} \mathrm{O}$ values clearly differ and ranges from -3.4 to $+0.53 \%$ V-PDB for fissure ridge and -9.3 to $-5.7 \%$ V-PDB for mound calcites. Moreover, the variety of diagenetic features in mound carbonates, which are almost absent in fissure ridge carbonates, indicates that mound fabrics are more susceptible to diagenetic alteration. The latter has been explained by their more porous nature. Mixing of mound related-fluids with meteoric water during resurfacing is the scenario explaining the $\delta^{18} \mathrm{O}$ difference, which is in agreement with the micritic nature of the mound geobody. The latter has been related to the inferred lower water saturation with respect to calcite. The sparitic fabric in fissure ridge carbonates is more in agreement with high calcite saturation.

Therefore, the fissure-ridge precipitated from dominantly subsurface-sourced fluids without major contribution of meteoric water. This can explain the rather high $\delta^{18} \mathrm{O}$ values of the fissure ridge carbonates which is in line with the rather high $\mathrm{S}$ and $\mathrm{Sr}$ content of the fissure ridge carbonates. The presence of two different types of bedrock, i.e. limestone and volcanic rock (tuff and lapilli/pumiceous) with different permeability and porosity is proposed to be the main controlling factor why the upwelling water chemistry was so different.

Additional support for this interpretation comes from the geochemical analysis. Non-carbonate related elemental concentrations, such as $\mathrm{Al}, \mathrm{As}, \mathrm{K}, \mathrm{Fe}, \mathrm{Mn}, \mathrm{Rb}, \mathrm{P}, \mathrm{Ti}, \mathrm{Cr}, \mathrm{Ni}$ and $\mathrm{Mg}$ are higher in mound carbonates while calcite-related elements (like $\mathrm{Sr}, \mathrm{S}$ and $\mathrm{Ca}$ ) are higher in fissure ridge carbonates. Noncarbonate related elements were sourced either from the internal alteration of the substrate during water upwelling or from the surrounding area as a result of weathering and erosion by meteoric water. The source of the high $\mathrm{Sr}$ and $\mathrm{S}$ content in the fissure ridge and mound carbonates is explained by the evaporite layers present in the Qom Formation. The dominance of bright luminescence calcites in fissure ridge and in some parts of mound carbonates is due to the high concentrations of dissolved $\mathrm{Mn}$ in the parent fluid, indicating precipitation and/or recrystallisation under calcite supersaturated and suboxic conditions. 


\section{Acknowledgements}

The authors are grateful to Prof. Dr. Ir. S. Bouillon and colleagues of the Department of Earth and Environmental Sciences of the KU Leuven (Belgium) for performing the oxygen and carbon stable isotope measurements. Prof. Dr. N. Mattielli (Université libre de Bruxelles (ULB)) is gratefully appreciated for performing the strontium isotope. Mr. K. Amjadian and Mr. H. Abbasi are thanked for their help during fieldwork. H. Nijs is acknowledged for the careful preparation of thin sections and Dr. E. Vassilieva for the ICP-OES analysis. This work was supported by KU Leuven research and development.

\section{Reference}

Akdim, B., Julia, R.A., 2005. The travertine mounds of Tafilalet Morocco. Morphology and genesis based on present-day analogues. Zeitschrift Fur Geomorphologie 49 (3), 373-389.

Altunel, E. Hancock, P. L. 1993a. Active fissuring and faulting in Quaternary travertines at Pamukkale, western Turkey. In Neotectonics and Active Faulting (eds I. S. Stewart, C. Vita-Finzi and L. A. Owen). Zeitschrift fuer Geomorphologie Supplement 94, 285-302.

Altunel, E. Hancock, P. L., 1993b. Morphology and structural setting of Quaternary travertines at Pamukkale, Turkey. Geological Journal 28, 335-46.

Altunel E., Hancock P.L., 1996. Structural attributes of travertine-filled extensional fissures in the Pamukkale Plateau, Western Turkey. International Geology Review, 38, 768-777.

Amieux, P., Bernier, P., Dalongeville, R., de Medwecki, V., 1989. Cathodoluminescence of carbonatecemented Holocene beachrock from the Togo coastline (West Africa): An approach to early diagenesis. Sedimentary Geology, 65, 261-272.

Andrews, J.E., 2006. Palaeoclimatic records from stable isotopes in riverine tufas: synthesis and review. Earth-Science Reviews, 75 (1-4), 85-104.

Arenas, C., Pomar, L., 2010. Microbial deposits in upper Miocene carbonates, Mallorca, Spain. Palaeogeography, Palaeoclimatology, Palaeoecology, 297(2), 465-485. 
Azizi, H., Jahangiri, A., 2008. Cretaceous subduction-related volcanism in the northern Sanandaj-Sirjan Zone, Iran. Journal of Geodynamics, 45, 178-190.

Azizi, H., Moinevaziri, H., 2009. Review of the tectonic setting of Cretaceous to quaternary volcanism in northwestern Iran. Journal of Geodynamics 47, 167-179.

Azizi, H., Asahara, Y., Tsuboi, M., 2013. Quaternary high-Nb basalt: existence of young oceanic crust under the Sanadaj-Sirjan zone, NW Iran. International Geology Review, 56, 167-186.

Azizi, H., Asahara, Y., Tsuboi, M., Takemura, K. and Razyani, S., 2014. The role of heterogenetic mantle in the genesis of adakites northeast of Sanandaj, northwestern Iran. Chemie der ErdeGeochemistry, 74(1), 87-97.

Baharifar, A., Moinevaziri, H., Bellon, H., and Pique, A., 2004. The crystalline complexes of Hamadan (Sanandaj-Sirjan zone, western Iran): Meta sedimentary Mesozoic sequences affected by Late Cretaceous tectono-metamorphic and plutonic events. Comptes Rendus Geosciences, 336, 14431452.

Ballato, P., Uba, C.E., Landgraf, A., Strecker, M.R., Sudo, M., Stockli, D.F., Friedrich, A., Tabatabaei, S.H., 2011. Arabia-Eurasia continental collision: Insights from late Tertiary foreland-basin evolution in the Alborz Mountains, northern Iran. Bulletin, 123(1-2), 106-131.

Barth, J. A., Chafetz, H. S., 2015. Cool water geyser travertine: Crystal Geyser, Utah, USA. Sedimentology, 62(3), 607-620.

Berardi, G., Vignaroli, G., Billi, A., Rossetti, F., Soligo, M., Kele, S., Baykara, M.O., Bernasconi, S.M., Castorina, F., Tecce, F., Shen, C.C., 2016. Growth of a Pleistocene giant carbonate vein and nearby thermogene travertine deposits at Semproniano, southern Tuscany, Italy: Estimate of $\mathrm{CO}_{2}$ leakage. Tectonophysics, 690, 219-239.

Boccaletti, M., Innocenti, F., Manetti, P., Mazzuoli, T., Motamed, A., Pasquare, G., Radicati di Brozolo, F., Amin Sobhani, E., 1976. Neogene and Quaternary volcanism of the Bijar area (Western Iran). Bulletin of Volcanology 40, 121-132. 
Boggs, S., Kingsley, D., 2006. Application of cathodoluminescence imaging to the study of sedimentary rock. Cambridge University Press, 165.

Brogi, A. and Capezzuoli, E., 2009. Travertine deposition and faulting: The fault-related travertine fissure-ridge at Terme S. Giovanni, Rapolano Terme (Italy). Geologische Rundschau, 98, 931-947.

Brogi, A., Capezzuoli, E., 2014. Earthquake impact on fissure-ridge type travertine deposition. Geological Magazine, 151, 1135-1143.

Capezzuoli, E., Gandin, A., Pedley, M., 2014. Decoding tufa and travertine (fresh water carbonates) in the sedimentary record: the state of the art. Sedimentology, 61, 1-21.

Carminatti, M., Wolff, B., Gamboa, L., 2008. New exploratory frontiers in Brazil: Proceedings of the 19th World Petroleum Congress, Madrid, Spain, June 29-July 3, 2008, 11 p.

Chafetz, H.S., Guidry, S.A., 1999. Bacterial shrubs, crystal shrubs, and ray-crystal shrubs: bacterial vs. abiotic precipitation. Sedimentary Geology 126, 57-74.

Chafetz, H.S., Folk R.L., 1984. Travertines: Depositional morphology and the bacterially-constructed constituents. Sedimentary Petrology, 54, 299-316.

Chafetz, H.S., Rush, P.F., Utech, N.M., 1991a. Microenvironmental controls on mineralogy and habit of $\mathrm{CaCO}_{3}$ precipitates: an example from an active travertine system. Sedimentology, 38, 107-126.

Chafetz, H.S., Utech, N.M., Fitzmaurice, S.P., 1991b. Differences in the $\delta^{18} \mathrm{O}$ and $\delta^{13} \mathrm{C}$ signatures of seasonal laminae comprising travertine stromatolites: Journal of Sedimentary Petrology, 61, $1015-1028$.

Claes, H., Soete, J., Van Noten, K., El Desouky, H., Erthal, M. M., Vanhaecke, F., Özkul, M. and Swennen, R., 2015. Sedimentology, three-dimensional geobody reconstruction and carbon dioxide origin of Pleistocene travertine deposits in the Ballk area (south-west Turkey). Sedimentology, 62, 1409-1445.

Claes, H., Marques Erthal, M., Soete, J., Özkul, M., Swennen, R., 2017a. Shrub and pore type 
classification: Petrography of travertine shrubs from the Ballık-Belevi area (Denizli, SW Turkey). Quaternary International, 437, 147-163.

Claes, H., Degros, M., Soete, J., Claes, S., Kele, S., Mindszenty, A., Török, Á, El Desouky, H., Vanhaecke, F., Swennen, R., 2017b. Geobody architecture, genesis and petrophysical characteristics of the Budakalász travertines, Buda Hills (Hungary). Quaternary International, 437, $107-128$.

Croci, A., Della Porta, G., and Capezzuoli, E., 2016. Depositional architecture of a mixed travertineterrigenous system in a fault-controlled continental extensional basin (Messinian, Southern Tuscany, Central Italy). Sedimentary Geology, 332, 13-39.

Crombie, M.K., Arvidson, R.E., Sturchio, N.C., ElAlfy, Z., AbuZeid, K., 1997. Age and isotopic constraints on Pleistocene pluvial episodes in the Western Desert, Egypt. Palaeogeography, Palaeoclimatology, Palaeoecology, 130 (1-4), 337-355.

Curewitz, D. and Karson, J.A., 1997. Structural setting of hydrothermal outflow: Fracture permeability maintained by fault propagation and interaction. Volcanology and Geothermal Research, 79, 149168.

De Boever, E., Foubert, A., Lopez, B., Swennen, R., Jaworowski, C., Özkul, M., Virgone, A., 2016. Comparative study of the Pleistocene Cakmak quarry (Denizli Basin, Turkey) and modern Mammoth Hot Springs deposits (Yellowstone National Park, USA). Quaternary International, 437, 129-146.

De Filippis, L., Billi, A., 2012. Morphotectonics of fissure ridge travertines from geothermal areas of Mammoth Hot Springs (Wyoming) and Bridgeport (California). Tectonophysics, 548,34-48.

De Filippis, L., Anzalone, E., Billi, A., Faccenna, C., Poncia, P.P., Sella, P., 2013. The origin and growth of a recently-active fissure ridge travertine over a seismic fault, Tivoli, Italy. Geomorphology, $195,13-26$.

Della Porta, G., 2015. Carbonate build-ups in lacustrine, hydrothermal and fluvial settings: comparing 
depositional geometry, fabric types and geochemical signature. Microbial Carbonates in Space and Time: Implications for Global Exploration and Production. Geological Society, London, Special Publications , 418, 17-68.

Della Porta, G., Capezzuoli, E., De Bernardo, A., 2017. Facies character and depositional architecture of hydrothermal travertine slope aprons (Pleistocene, Acquasanta Terme, Central Italy). Marine and Petroleum Geology, 87, 171-187.

Dunham, R.J., 1962. Classification of carbonate rocks according to depositional texture. - In: W.E. Ham (ed.), Classification of Carbonate Rocks. American Association of Petroleum Geologists, Tulsa, Oklahoma, Memoirs, 1, 108-121.

El Desouky, H., Soete, J., Claes, H., Özkul, M., Vanhaecke, F., Swennen, R., 2015. Novel applications of fluid inclusions and isotope geochemistry in unravelling the genesis of fossil travertine systems. Sedimentology, 62, 27-56.

Embry III, A.F., Klovan, J.E., 1971. A late Devonian reef tract on northeastern Banks Island, NWT. Bulletin of Canadian Petroleum Geology, 19(4), 730-781.

Erthal, M.M., Capezzuoli, E., Mancini, A., Claes, H., Soete, J., Swennen, R., 2017. Shrub morpho-types as indicator for the water flow energy - Tivoli travertine case (Central Italy). Sedimentary Geology, 347, 79-99.

Eustáquio Moreira Lima, B., De Ros., L. B., 2019. Deposition, diagenetic and hydrothermal processes in the Aptian Pre-Salt lacustrine carbonate reservoirs of the northern Campos Basin, offshore Brazil. Sedimentary Geology, 383, 55-81.

Folk, R.L., Chafetz, H.S., Tiezzi, P.A., 1985. Bizarre forms of depositional and diagenetic calcite in hot-spring travertines, central Italy: The Society of Economic Paleontologists and Mineralogists, $36,349-369$.

Ford, T.D., Pedley, H.M., 1996. A review of tufa and travertine deposits of the world. Earth-Science Reviews, 41, 117-175. 
Fouke, B.W., 2011. Hot-spring Geobiology: abiotic and biotic influence on travertine formation at Mammoth Hot Springs, Yellowstone National Park, USA. Sedimentology, 59, 170-219.

Frizon de Lamotte, D., Raulin, C., Mouchot, N., Wrobel-Daveau, J. C., Blanpied, C., Ringenbach, J. C., 2011. The southernmost margin of the Tethys realm during the Mesozoic and Cenozoic: Initial geometry and timing of the inversion processes. Tectonics, 30, Tc3002.

Gandin, A., Capezzuoli, E., 2008. Travertine versus calcareous tufa: Distinctive petrologic features and stable isotopes signatures. Italian Journal of Quaternary Sciences, 21(1B), 125-136.

Gandin, A., Capezzuoli, E., 2014. Travertine: Distinctive depositional fabrics of carbonates from thermal spring systems. Sedimentology, 61, 264-290.

Ghasemi, A., Talbot, C.J., 2006. A new tectonic scenario for the Sanandaj-Sirjan Zone (Iran). Journal of Asian Earth Sciences, 26, 683-693.

Gillikin, D.P. and Bouillon, S., 2007. Determination of $\delta^{18} \mathrm{O}$ of water and $\delta^{13} \mathrm{C}$ of dissolved inorganic carbon using a simple modification of an elemental analyser-isotope ratio mass spectrometer: an evaluation. Rapid Communications in Mass Spectrometry: An International Journal Devoted to the Rapid Dissemination of Up-to-the-Minute Research in Mass Spectrometry, 21(8),1475-1478.

Gran, G., 1952. Determination of the equivalence point in potentiometric titrations. Part II. Analyst, 77(920), 661-671.

Guido, D. M., and Campbell, K. A., 2012. Diverse subaerial and sublacustrine hot spring settings of the Cerro Negro epithermal system (Jurassic, Deseado Massif), Patagonia, Argentina. Volcanology and Geothermal Research, 229-230, 1-12.

Guo, L., Riding, R., 1992. Aragonite laminae in hot water travertine crusts, Rapolane Terme, Italy. Sedimentology, 39, 1067-1079.

Guo, L., Riding, R., 1994. Origin and diagenesis of Quternary continental carbonate shrub fabrics, Rapolano Terme, central Italy. Sedimentology 41, 499-520. 
Guo, L., Andrews, J., Riding, R., Dennis, P., Dresser, Q., 1996. Possible microbial effects on stable carbonisotopes in hot-spring travertines. Journal of Sedimentary Research, 66, 468-473.

Guo, L., Riding, R., 1998. Hot-spring travertine facies and sequences, Late Pleistocene, Rapolano Terme, Italy. Sedimentology, 45, 163-190.

Guo, L., Riding, R., 1999. Rapid facies changes in Holocene fissure ridge hot spring travertines, Rapolano Terme, Italy. Sedimentology, 46, 1145-1158.

Hancock, P.L., Chalmers R.M.L., Altunel, E., Çakir, Z., 1999. Travitonics: using travertines in active fault studies. Journal of Structural Geology, 21, 903-916.

Hassanzadeh, J., Wernicke, B.P., 2016. The Neotethyan Sanandaj-Sirjan zone of Iran as an archetype for passive margin-arc transitions. Tectonics, 35(3), 586-621.

Herlinger, R., Zambonato, E. E., Ros, L. F. D. E., 2017. Influence of diagenesis on the quality of lower cretaceous pre-salt lacustrine carbonate reservoirs from northern Campos Basin, offshore Brazil. Journal of Sedimentary Research, 87, 1285-1313.

Hoefs, J., 2004. Stable Isotope Geochemistry. 5th Edition. Berlin, Germany: Springer-Verlag. 244 pp.

Hosseiny, M., 1999. Geology map of Sanandaj scale (1:100000). Geological Survey of Iran.

Jones, B., Renaut, R.W., 1995. Noncrystallographic calcite dendrites from hot-spring deposits at Lake Bogoria, Kenya. Journal of Sedimentary Research, 65, 154-169.

Jones, B., Renaut, R.W., 2010. Calcareous spring deposits in continental settings. In: Continental Settings: Facies, Environments and Processes. (Eds A.M. Alonso-Zarza and L.H. Tanner), Elsevier, Amsterdam, 177-224 pp.

Kallis, P., Bleich, K.E., Stahr, K., 2000. Micromorphological and geochemical characterization of Tertiary 'freshwater carbonates' locally preserved north of the edge of the Miocene Molasse Basin (SW Germany). Catena, 41, 19-42.

Karimi Nezhad, M. T., Mohammadi, K., Gholami, A., Hani, A., Shariati, M. S., (2014). Cadmium and 
mercury in topsoils of Babagorogor watershed, western Iran: Distribution, relationship with soil characteristics and multivariate analysis of contamination sources. Geoderma, 219-220, 177-185.

Kele, S., Demény, A., Siklósy, Z., Németh, T., Tóth, M., Kovács, M.B., 2008. Chemical and stable isotope composition of recent hot-water travertines and associated thermal waters, from Egerszalók, Hungary: Depositional facies and non-equilibrium fractionation. Sedimentary Geology, 211(3-4), 53-72.

Kele, S., Özkul, M., Fórizs, I., Gökgöz, A., Baykara, M. O., Alçiçek, M. C., Németh T., 2011. Stable isotope geochemical study of Pamukkale travertines: New evidences of low-temperature nonequilibrium calcite-water fractionation. Sedimentary Geology, 239, 191-212.

Keppel, M.N., Clarke, J.D.A., Halihan, T., Love, A.J., Werner, A.D., 2011. Mound springs in the arid Lake Eyre South region of South Australia: a new depositional tufa model and its controls. Sedimentary Geology, 240, 55-70.

Linares, R., Rosell, J., Roque, C., Gutierrez, F., 2010. Origin and evolution of tufa mounds related to artesian karstic springs in Isona area (Pyrenees, NE Spain). Geodynamica Acta, 23 (1-3), 129150.

Lottaroli, F., Meciani, L., Andreotti, P., Cornaggia, F., 2012. West Africa Pre-salt exploration: background and Perspective of the West African "Tupi” myth. In: New Understanding of the Petroleum Systems of Continental Margins of the World: GCS SEPM, 460-468.

Machel, H.G., Mason, R.A., Mariano, A.N., Mucci, A., 1991. Causes and emission of luminescence in calcite and dolomite. In: Luminescence Microscopy and Spectroscopy - Qualitative and quantitative applications (Eds C.E. Barker and O.C. Kopp), pp. 9-25, SEPM Short Course, 25, 925.

Machel, H., 2000. Application of cathodoluminescence to carbonate diagenesis. In: Cathodoluminescence in Geosciences (Eds M. Pagel, V. Barbin, P. Blanc and D. Ohnenstetter). Springer-Verlag, Berlin Heidelberg. pp. 271-301. 
Malecootyan, S., Hagh-Nazar, S.H., Ghorbani, M., Emami, M.H., 2007. Magmatic evolution in quaternary basaltic rocks in Sanandaj-Takab axis. Geosciences Scientific Quarterly Journal (Geological Survey of Iran) 64, 166-178 (in Persian with English abstract).

Mallick, R. and Frank, N., 2002. A new technique for precise uranium-series dating of travertine microsamples. Geochimica et Cosmochimica Acta, 66(24), 4261-4272.

Marshall, D. J., 1988. Cathodoluminescence of geological materials. Unwin Hyman, London, 146p.

McArthur, J.M., Howarth, R.J., 2004. Sr-isotope stratigraphy: the Phanerozoic ${ }^{87} \mathrm{Sr} /{ }^{86} \mathrm{Sr}$ curve and explanatory notes. In: A Geological Timescale (Eds F. Gradstein, J. G. Ogg and A.G. Smith), 96105. Cambridge University press, Mouscron.

Miall, A.D., 1996. The Geology of Fluvial Deposits. Springer Verlag, Berlín, p. 582.

Minissale, A., Kerrick, D.M., Magro, G., Murrell, M.T., Paladini, M., Rihs, S., Sturchio, N.C., Tassi, F. and Vaselli, O., 2002. Geochemistry of Quaternary travertines in the region north of Rome (Italy): structural, hydrologic and paleoclimatic implications. Earth and Planetary Science Letters, 203(2), 709-728.

Mohajjel, M., Fergusson, C.L., Sahandi, M.R., 2003. Cretaceous-Tertiary convergence and continental collision, Sanandaj-Sirjan Zone, western Iran: Journal of Asian Earth Sciences, 21, 397-412.

Mohammadi, Z., Claes, H., Capezzuoli, E., Mozafari, M., Soete, J., Aratman, C., Swennen, R., 2019. Lateral and vertical variations in sedimentology and geochemistry of sub-horizontal laminated travertines (Çakmak quarry, Denizli Basin, Turkey), Quaternary International doi: https://doi.org/10.1016/j.quaint.2018.11.041.

Okay, A. I., Zattin, M., Cavazza, W., 2010. Apatite fission-track data for the Miocene Arabia-Eurasia collision. Geology, 38, 35-38.

Özkul, M., Varol, B., Alçiçek, M.C., 2002. Depositional environments and petrography of Denizli travertines. Bulletin of the Mineral Research and Exploration, 125, 13-29. 
Panichi, C., Tongiorgi, E., 1976. Carbon isotopic composition of CO2 from springs, fumaroles, mofettes and travertines of Central and Southern Italy: a preliminary prospection method of geothermal area. Proceedings of the 2nd U.N. Symposium on Development and Use of Geothermal Resources, 1975: San Francisco, 815-825.

Pentecost, A., Viles, H., 1994. A Review and Reassessment of Travertine Classification. Géographie physique et Quaternaire, 48, 3, 305-314.

Pentecost, A., 2005. Travertine. Springer-Verlag, Berlin Heidelberg. 445 pp.

Pola, M., Gandin, A., Tuccimei, P., Soligo, M., Deiana, R., Fabbri, P., Murialdo, S. L., 2014. A multidisciplinary approach to understanding carbonate deposition under tectonically controlled hydrothermal circulation: A case study from a recent travertine mound in the Euganean hydrothermal system, northern Italy. Sedimentology, 61, 172-199.

Rahmani, S. 2012. Geochemistry and sedimentary environment of travertine in Central and SanandajSirjan Zone (Western Iran). Master thesis, Hamadan university, Iran. 120 pp.

Razavi, M.H., Sayyareh, A., 2010. Properties of young volcanic rocks in southeast of Bijar: Geosciences (In Persian with English abstract) 74, 151-156.

Reuter, M. Piller, W. E., Harzhauser, M., Mandic, O., Berning, F., Kroh, A., Aubry, M. P., WielandtSchuster, U., Hamedani. A., 2009. The Oligo- Miocene Qom Formation (Iran ): evidence for an early Burdigalian restriction of the Tethyan Seaway and closure of its Iranian gateways: International Journal of Earth Sciences, 98, 627-650.

Richter, D.K., Götte, T., Götze, J. and Neuser, R.D., 2003. Progress in application of cathodoluminescence (CL) in sedimentary petrology. Mineralogy and Petrology, 79(3-4), 127166.

Richards, J. P., Wilkinson, D., Ullrich, T., 2006. Geology of the Sari Gunay epithermal gold deposit, northwest Iran. Economic Geology, 101, 1455-1496.

Rodríguez-Berriguete, Á., Alonso-Zarza, A.M., Martín-García, R. and Cabrera, M.D.C., 2018. 
Sedimentology and geochemistry of a human-induced tufa deposit: Implications for palaeoclimatic research. Sedimentology, 65(7), 2253-2277.

Ronchi, P., Cruciani, F., 2015. Continental carbonates as hydrocarbon reservoir, an analogue case study from the travertine of Saturnia, Italy. AAPG Bulletin, 99, 711-734.

Roshanak, R., Moore, F., Zarasvandi, A., Keshavarzi, B., Gratzer, R., 2018. Stable isotope geochemistry and petrography of the Qorveh-Takab travertines in northwest Iran. Austrian Journal of Earth Sciences, 111/1, 064-074.

Saller, A., Rushton, S., Buambua, L., Inman, K., McNeil, R., Dickson, J. A. D., 2016. Presalt stratigraphy and depositional system in the Kwanza Basin, offshore Angola. AAPG Bulletin, 100, $1135-1164$.

Sant'Anna, L.G., Riccomini, C., Rodrigues-Francisco, B.H., Sial, A.N., Carvalho, M.D., Moura, C.A.V., 2004. The Palaeocene travertine system of the Itaboraí basin, Southeastern Brazil, Journal of South American Earth Sciences, 18, 11-25.

Schröder, S., Ibekwe, A., Saunders, M., Dixon, R., and Fisher, A., 2016. Algal - microbial carbonates of the Namibe Basin (Albian, Angola): implications for microbial carbonate mound development in the South Atlantic Legend. Petroleum Geoscience, 22, 71-90.

Sepahi, A.A., Athari, S.F., 2006. Petrology of major granitic plutons of the northwestern part of the Sanandaj-Sirjan Metamorphic Belt, Zagros Orogen, Iran: With emphasis on A-type granitoids from the SE Saqqez area: Neues Jahrbuch für Mineralogie -Abhndlungen, 183, 93-106.

Sharp, I., et al., 2012. Pre- and Post-salt non-marine carbonates of the Namibe Basin, Angola. In: AAPG Annual Convention and Exhibition: AAPG Search and Discovery.

Sharp, I., Verwer, K., Ferreira, H., Lapponi, F., Snidero, M., Machado, V., Holtar, E., Swart, R., Marsh, J., Gindre, L., Puigdefabregas, C. and Fejerskov, M., 2013. Pre- and Post- Salt Non-Marine Carbonates of the Namibe Basin, Angola. Programme and abstract volume: microbial carbonates in space and time: implications for global exploration and production. Geological Society of 
America, 52, 19-20 June, 2013.

Sierralta, M., Kele, S., Melcher, F., Hambach, U., Reinders, J., van Gelderen, R., Frechen, M., 2010. Uranium series dating of travertine from Sutto: implications for reconstruction of environmental change in Hungary. Quaternary International, 222, 178-193.

Steiger, R. and Jäger, E., 1977. Subcommission on geochronology: convention on the use of decay constants in geo-and cosmochronology. Earth and planetary science letters, 36(3), pp.359-362.

Soete, J., Kleipool, L.M., Claes, H., Claes, S., Hamaekers, H., Kele, S., Özkul, M., Foubert, A., Reijmer, J.J.G., Swennen, R., 2015. Acoustic properties in travertines and their relation to porosity and pore types. Marine and Petroleum Geology, 59, 320-335.

Stocklin, J., 1968. Structural history and tectonics of Iran: a review. The American Association of Petroleum Geologists Bulletin 52 (7), 1229-1258.

Teboul, P., Kluska, J., Marty, N. C. M., Debure, M., and Durlet, C., 2017. Volcanic rock alterations of the Kwanza Basin, offshore Angola - Insights from an integrated petrological, geochemical and numerical approach. Marine and Petroleum Geology, 80, 394-411.

Temiz, U., Eikenberg, J., 2011. U/Th dating of the travertine deposited at transfer zone between two normal faults and their neotectonic significance: Cambazli ridge travertines (the Gediz Graben, Turkey). Geodinamica Acta, 24, 95-105.

Török, Á., Mindszenty, A., Claes, H., Kele, S., Fodor, L. and Swennen, R., 2017. Geobody architecture of continental carbonates:“Gazda” travertine quarry (Süttő, Gerecse Hills, Hungary). Quaternary International, 437, 164-185.

Uysal, I.T., Feng, Y., Zhao, J.X., Altunel, E., Weatherley, D., Karabacak, V., Cengiz, O., Golding, S.D., Lawrence, M.G., Collerson, K.D., 2007. U-series dating and geochemical tracing of late Quaternary travertine in co-seismic fissures. Earth and Planetary Science Letters, 257(3-4), 450462. 
Uysal, I.T., Feng, Y.X., Zhao, J.X., Isik, V., Nuriel, P., Golding, S.D., 2009. Hydrothermal $\mathrm{CO}_{2}$ degassing in seismically active zones during the late Quaternary. Chemical Geology, 265(3-4), $442-454$.

Williams, A.F., Holmes, J.W., 1978. A novel method of estimating the discharge of water from mound springs of the Great Artesian Basin, Central Australia. Journal of Hydrology, 38 (3), 263-272.

Wright, V.P., 2012. Lacustrine carbonates in rift settings: the interaction of volcanic and microbial processes on carbonate deposition: Geological Society, London, Special Publications, 370, 3947. 